\title{
The effectiveness of TREZ training on the philosophical mindfulness and metacognitive strategies of girl students
}

\author{
HasanAli Viskarami1 $^{\text {* }}$ (D), Zeinab Biyranvand ${ }^{2}$ Zahra Beyranvand $^{3}$ \\ 1. Assistant Professor of Psychology, Lorestan University, Khoram Abad, Iran \\ 2. PhD Student of Educational Psychology, Lorestan University, Khoram Abad, Iran \\ 3. MA in Educational Psychology, University of Mohaghegh Ardabili, Ardabil, Iran
}

Recieved: 19 Dec. 2018

Revised: 18 Jun. 2019

Accepted: 8 Jul. 2019

Keywords

TREZ

Philosophical mentality

Metacognitive strategies

Corresponding author

HasanAli Viskarami, Assistant Professor of Psychology, Lorestan University, Khoram Abad, Iran

Email: Veiskarami.h@lu.ac.ir

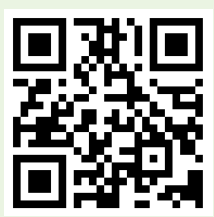

doi.org/10.30699/icss.21.4.128

\section{Abstract}

Introduction: The purpose of this study was to investigate the effect of TREZ training on philosophical mentality and metacognitive strategies in female students.

Methods: This quasi-experimental research was a pre-test, post-test design and follow-up with the control group. The statistical population of the study consisted of all third-grade female students in the second grade secondary school of Khorramabad in the academic year of 2017-2018. The 60 of them were selected by multi-stage random cluster sampling and then randomly assigned to two experimental and control groups (each group=30 subjects). The 6-session of 90-minute TREZ training conducted for the experimental group and one month after the end of the sessions, post-test and follow-up stages were performed. To collect data, philosophical subjective questionnaire and metacognitive strategies were used.

Results: The findings revealed the effectiveness of TREZ training on philosophical mentality and metacognitive strategies in female students in post-test and follow up stages. Conclusion: Consequently, the method has influenced the philosophical mentality and metacognitive strategies of female students. Therefore, it is suggested that teachers provide students with creativity and teaching methods during the training period.

Citation: Viskarami HA, Biyranvand Z, Beyranvand Z. The effectiveness of TREZ training on the philosophical mindfulness and metacognitive strategies of girl students. Advances in Cognitive Sciences. 2020;21(4):128-141. 


\title{
اثربخشى آموزش تريز بر ذهنيت فلسفى و راهبردهاى فراشناختى دانش آموزان دختر
}

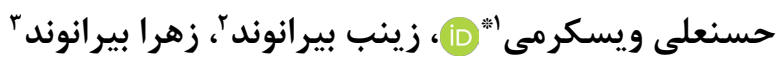 \\ I. استاديار كروه روانشناسى، دانشخاه لرستان، خرمآباد، ايران

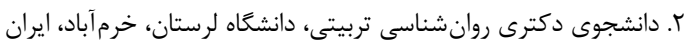

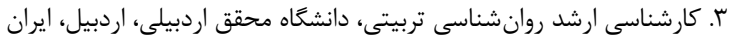

\begin{abstract}
حكبs
مقدمه: هدف يروهش حاضر، بررسى تأثير آموزش تريز (TREZ) بر ذهنيت فلسفى و راهبردهاى فراشناختى در دانش آموزان دختر بود.

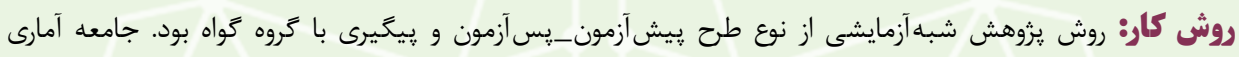

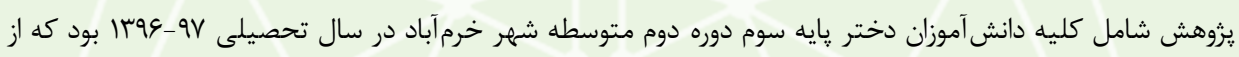
ميان آنها •و نفر به شيوه نمونه گيرى تصادفى خوشهاى جند مرحلهاى انتخاب و سيس به صورت تصادفى در دو كروه آزمايش و كواه جايخزين شدند (هر كروه • ب نفر). آموزش TREZ در كروه آزمايش به مدت 9 جلسه •و دقيقهاى اجرا شد و يك ماه بعد از اتمام جلسات، يس آزمون و مرحله بِيخيرى اجرا گرديد. براى جمع آورى دادهها از برسشنامههاى ذهنيت فلسفى و راهبردهاى فراشناختى استفاده شد. يافته ها: نتايج حاكى از اثربخشى آموزش TREZ بر ذهنيت فلسفى و راهبردهاى فراشناختى در دانش آموزان دختر در مراحل پِس آزمون و بِيكيرى بود. نتيجه گَيرى: مى توان نتيجه گرفت كه روش مزبور بر ذهنيت فلسفى و راهبردهاى فراشناختى دانش آموزان دختر تأثير كذاشته است لذا به معلمان بيشنهاد مى شود در طول دوره آموزش، خلاقيت و آموزش تريز را به دانشآموزان ارائه دهند.
\end{abstract} دريافت:

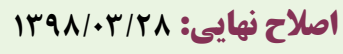

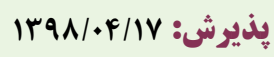
وارههاى كليدى تريز راهبردهاى فراشناختى فيتى نويسنده مسئول حسنعلى ويسكرمى، استاديار گروه روانشناسى، دانشعاه لرستان، خرمآباد، ايران ايميل:Veiskarami.h@lu.ac.ir

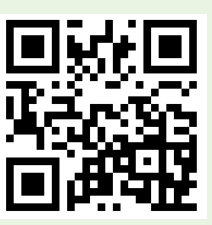

de

Doi.org/10.30699/icss.21.4.128
از يادگيرندگان از عهده يادگيرى آن بر نمىآيند و لازم است در اين

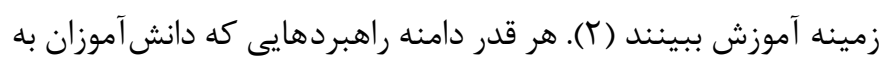
نحو مناسب به كار مى گيرند گسترده باشد موفقيت آنها در حل مسئله، خلاقيت، خواندن، درك مطلب و به خاطرسيارى اطلاعات بيشتر است (ז). ياد گيرندگانى كه از روشهاى مطالعه و يادگيرى خودشان آكاهى
امروزه مشكل بيشتر دانش آموزان اين است كه ياد نكرفتهاند كه جگَونه ياد بحيرند. راهبردهاى فراشناختى رفتارهايى هستند كه دانشآموزان در جريـان يادگيرى يا حل مسئله به طور فعال به كار مى گيرند تا عملكرد خودشان را تنظيم و هدايت كنند تا به يادگيرى و يادآورىشان كمك كند (1). هرجند اين راهبردها قابل يادگيرى هستند ولى بعضى 
سوى ديكر خلاقيت نيز منجر به نتاه جديد و متفاوت به يك موضوع

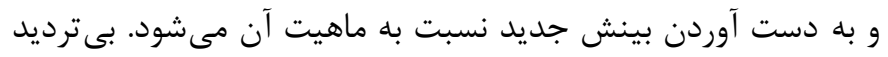

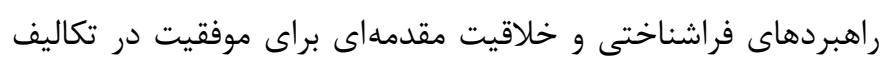

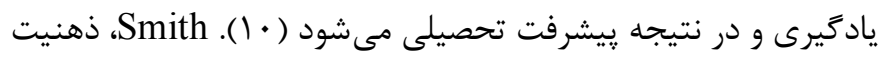

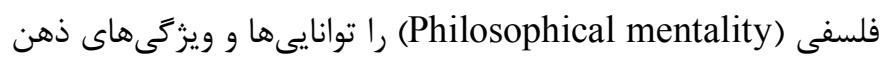

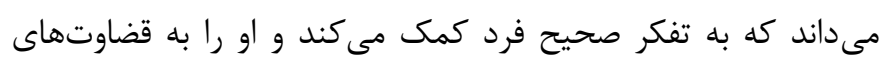

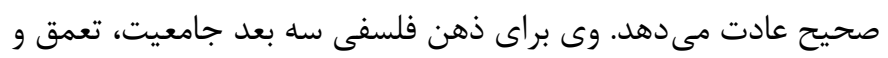

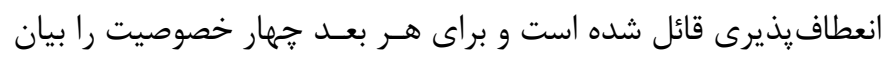

كرده است (1). (1). (1)

جامعيت (Comprehensiveness): (1) مشاهده امور خاص با توجـهـ

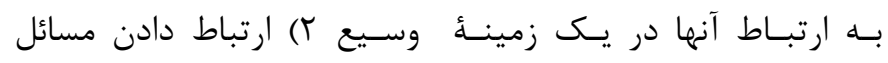

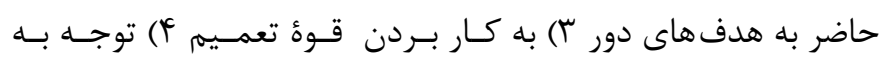

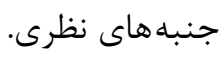

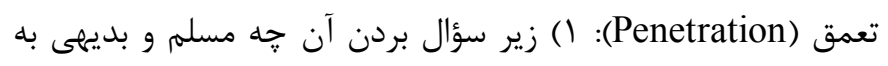

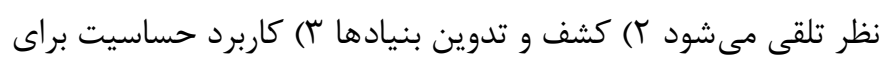

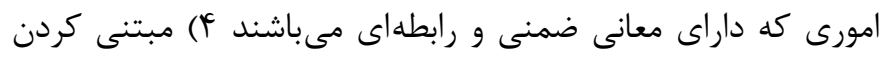
انتظارات بر جريان فرضيه استنتاجى_قياسى.

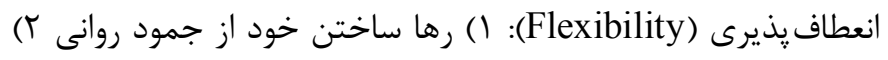

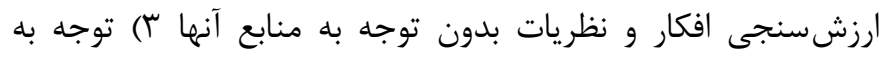

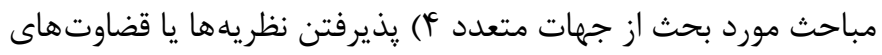

موقتى، شرطى و علاقه به اخذ تصميم در مواقع مبهرم ( I I). ميركمالى عقيده دارد تفكر منطقى، حاصل داشتن ذهن فله فلسفى است.

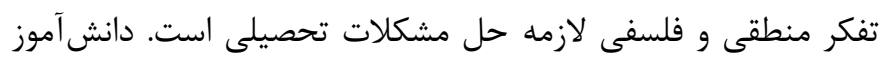

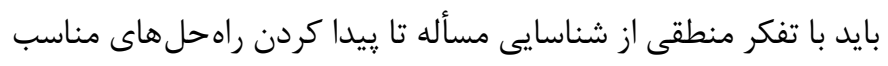

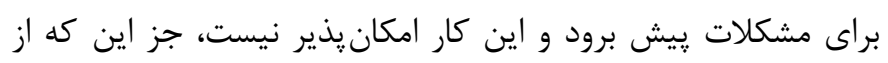

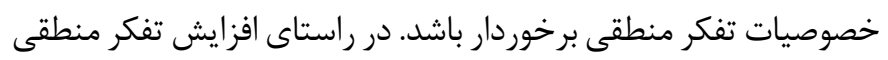

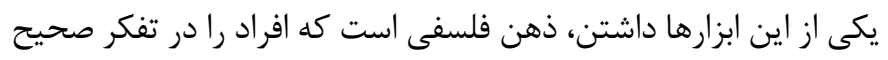

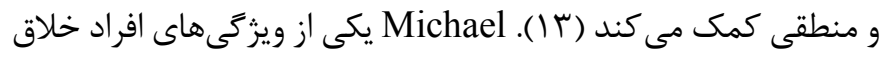

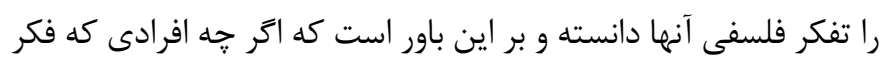

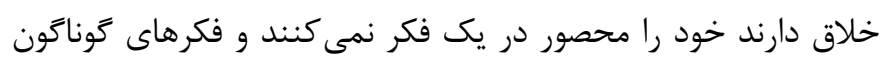

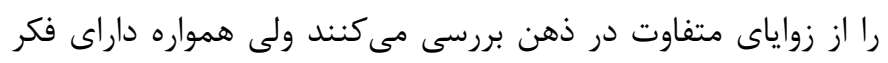

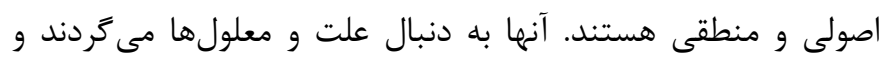

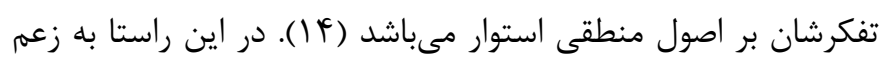

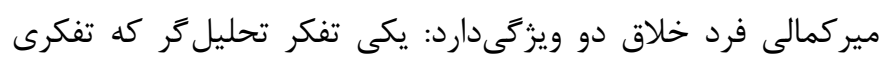

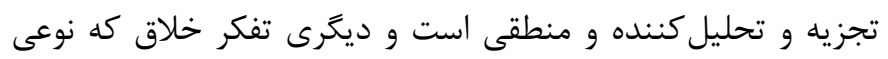
مهارت ذهنى است كه در آن قدرت تصور و انديشه به خلق ايدههاى جديد و نو به منظور دستيابى به يك يا جند راه حل مى يردازد (rآ).
دارند و به طور آكاهانه فعاليتهايى را براى بهبود آنها انتخاب مى كنند

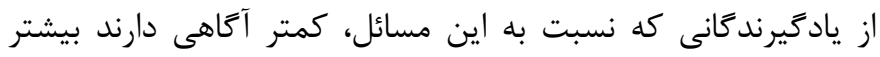

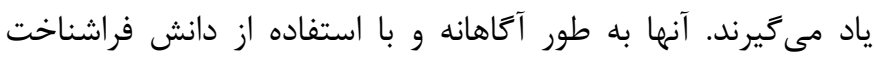

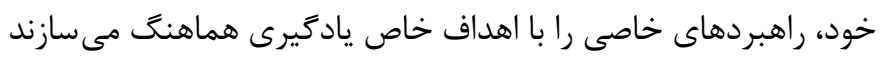

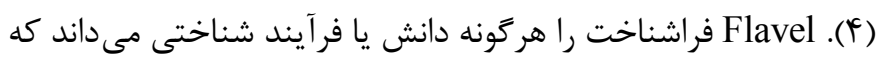

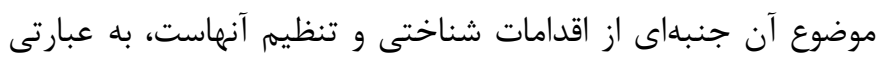

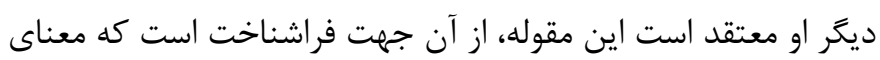

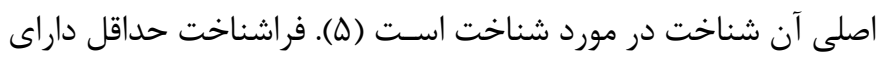
دو جزء دانش و كنترل است. منظور از دانش، آكاهى از مهارتها،

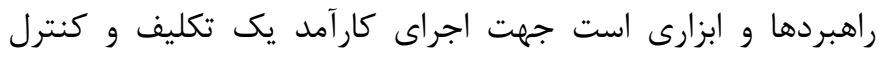

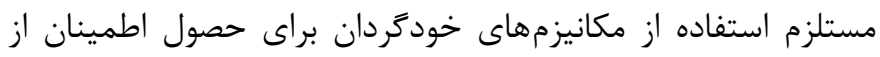

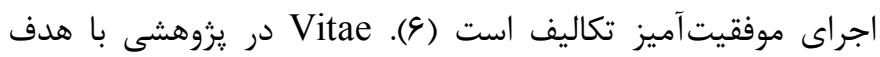
توصيف فراشناخت به معنى آكاهى و كنترل شناخت خود، آورده است،

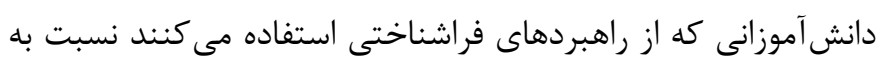

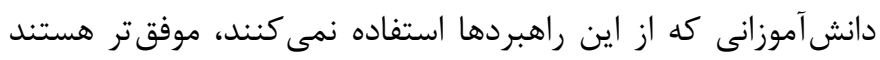

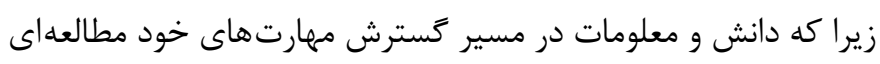

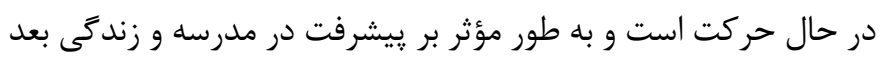

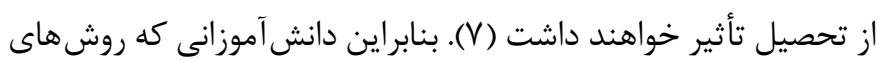

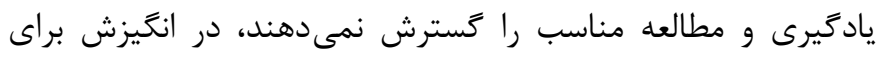

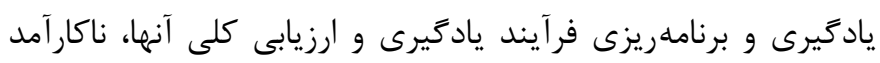

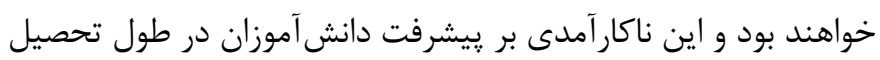

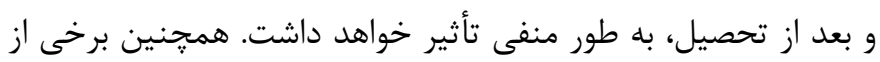

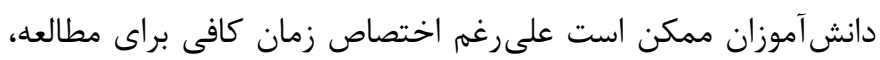

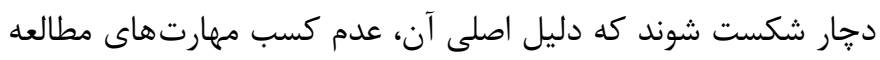

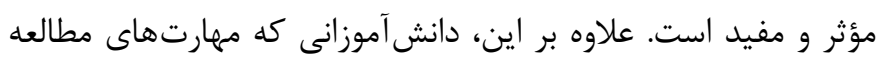

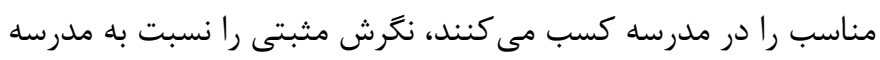

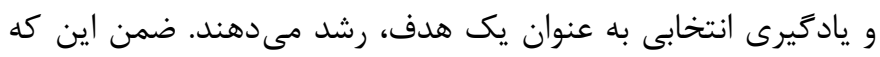
موفقيت كسب شده بعد از مطالعه مفيد موجب اطمينان خاطر و تشويق

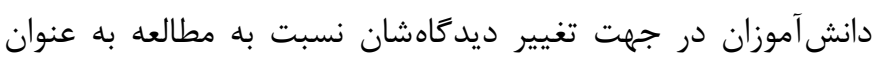

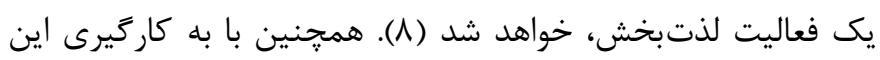

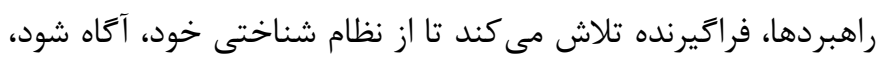

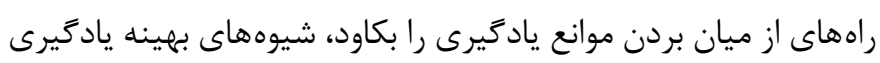

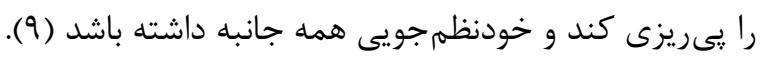

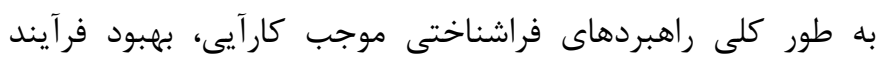

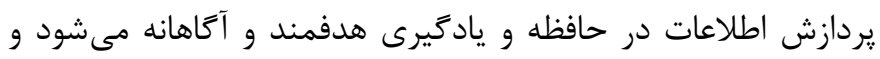
نقش مهمى در بهبود، انتقال و تعميم يادگيرى از يك موقعيت به

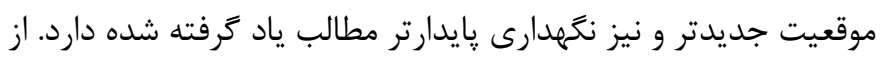


استعدادهاى بشرى براى رشد و شكوفايى نياز به دو شرط اساسى دارد:

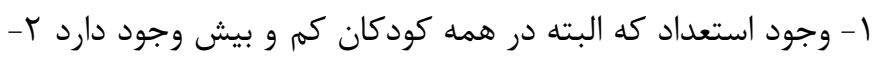

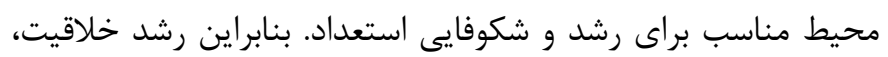

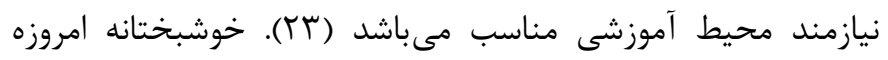

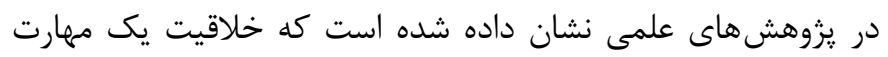

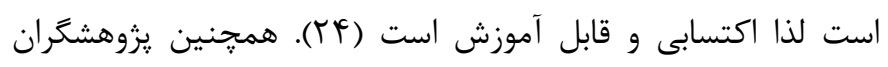
زيادى با يزوهشهايى كه انجام دادهاند به اين نتيجه رسيدهاند كه النه

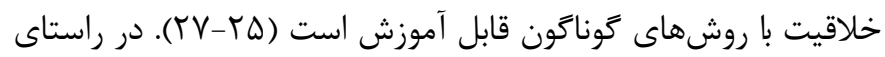

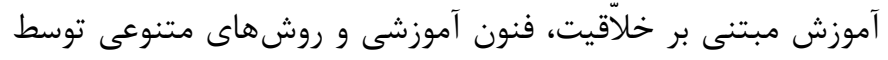

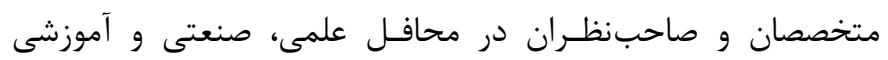

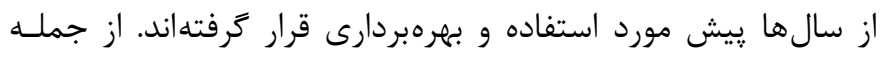

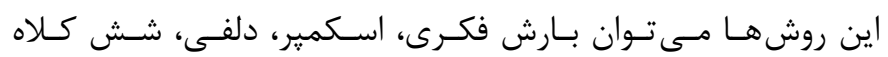

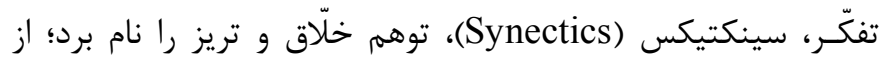

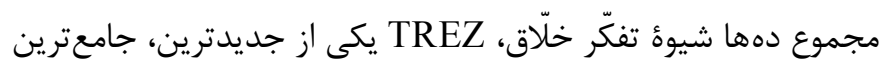

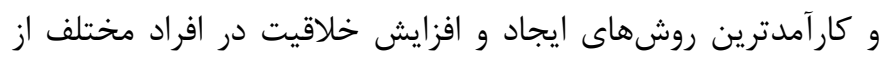

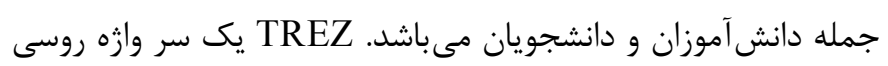

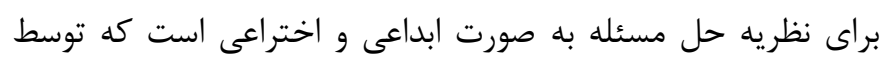

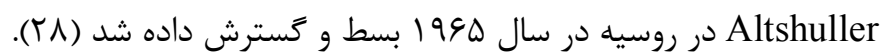
Altshuller

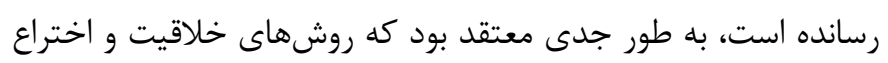

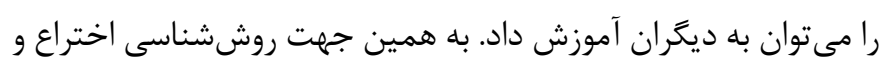

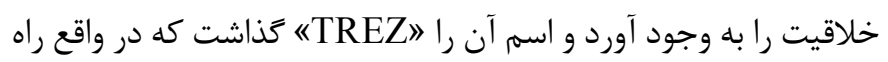

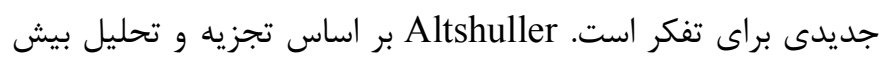

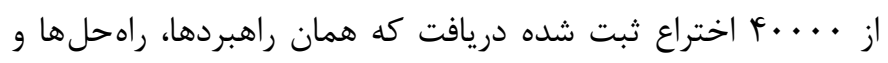
مسائل اساسى در يك حيطه و حوزه كه با خلاقيت آميخته است، توسط دأه

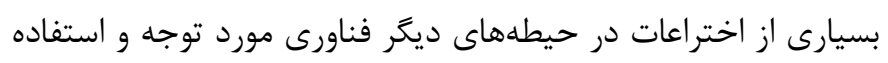

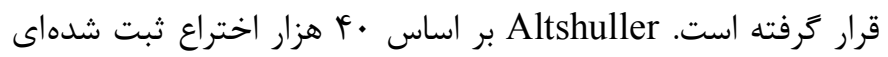

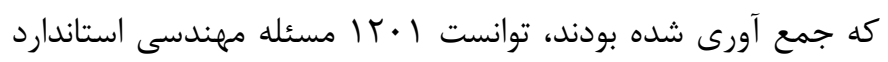

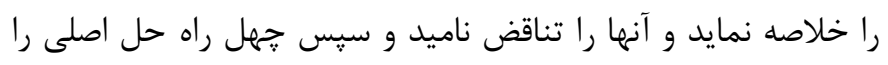

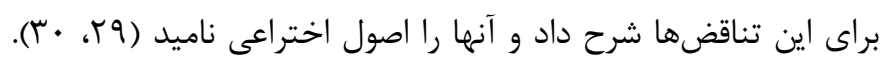
Savransky

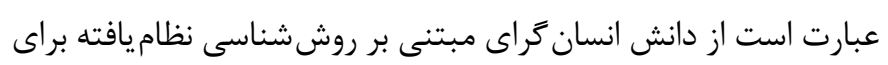

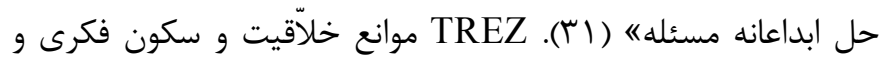

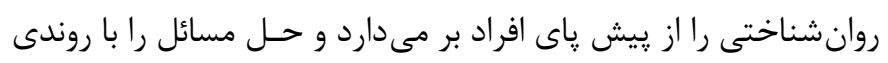

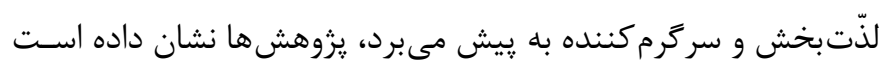

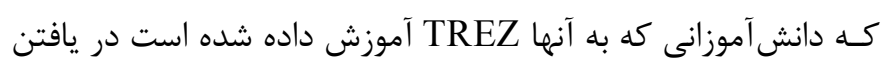

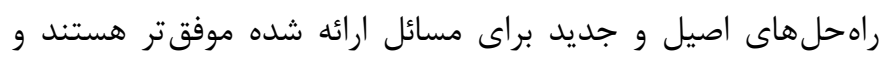

ذهن فلسفى به فرد بينش و دانشى مىدهد تا بتواند در مواجه با مسائل

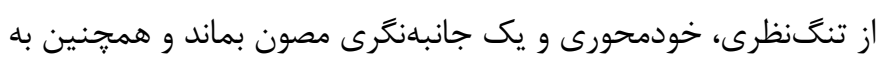

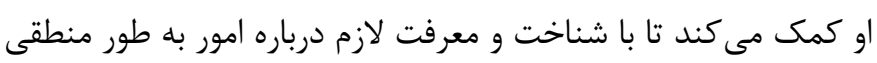

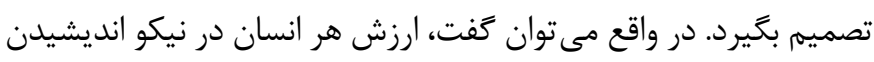

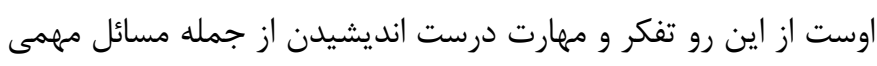

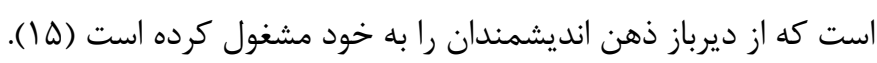

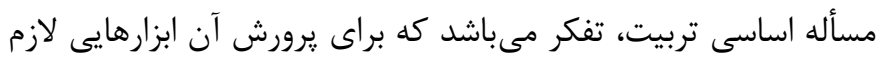

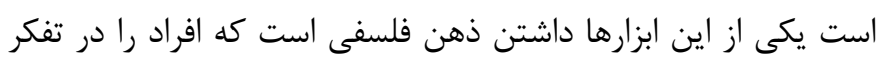

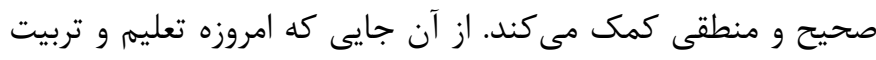

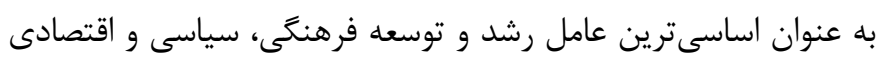

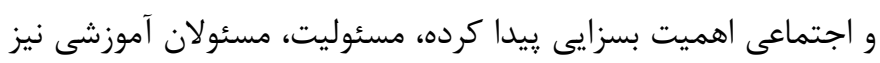

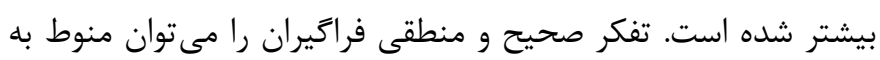

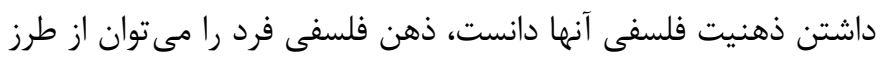

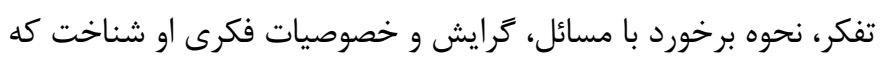

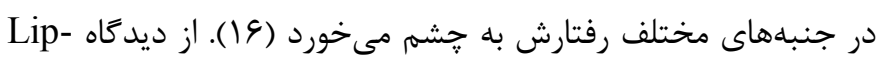

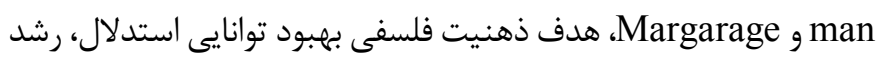

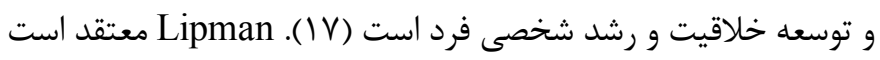

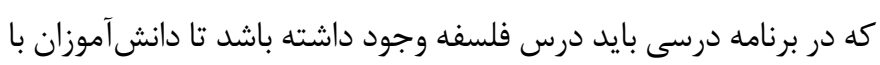
مفاهيم فلسفى آشنا شده تا در مراحل بعدى تفكر فلسفى در در آنان تقويت

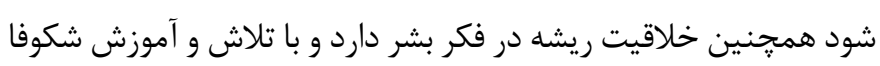

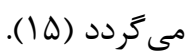

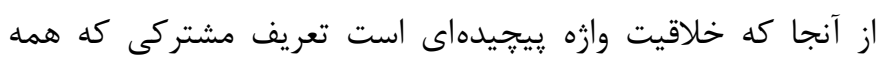

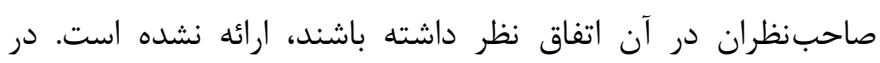

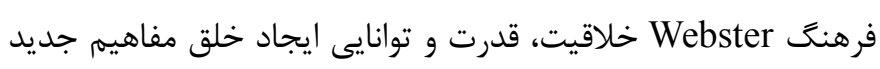

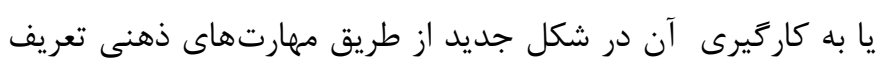

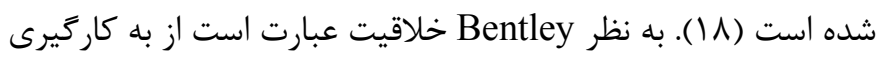

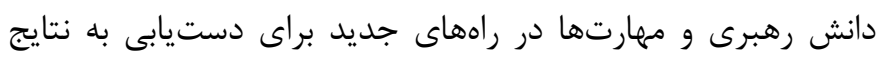

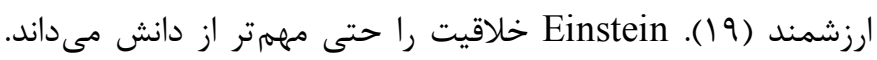
Hilgard

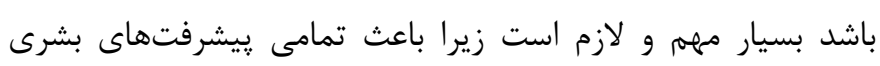

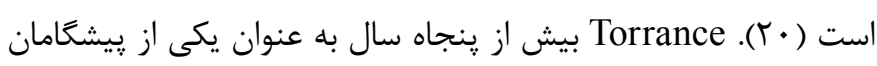

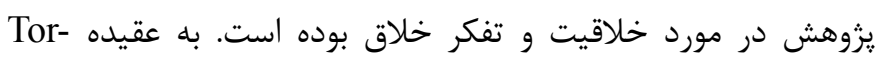

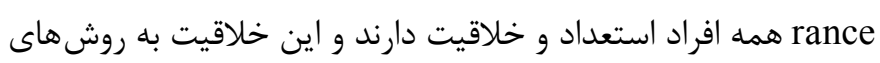

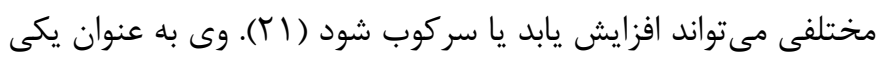

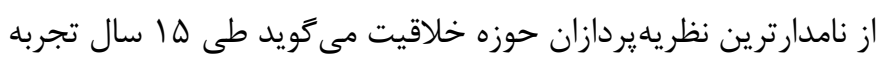

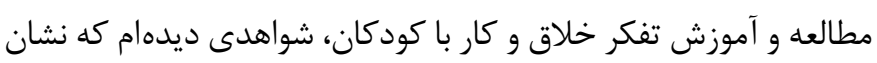

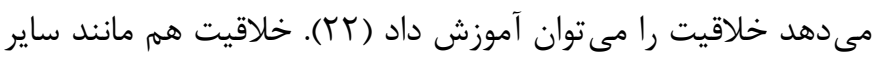


وظايف مديريتى در مدارس شهرستان ممسنى بررسى نموده و دريافت

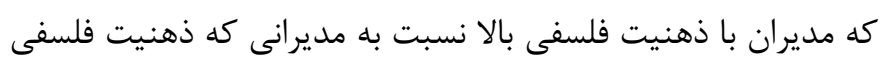

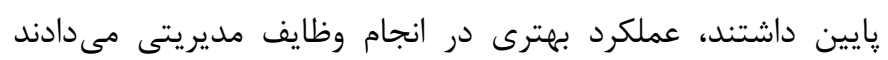

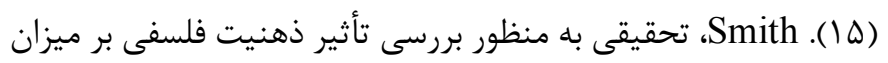

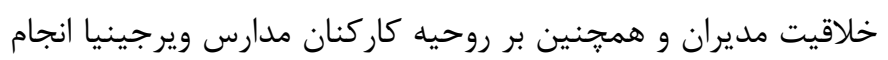

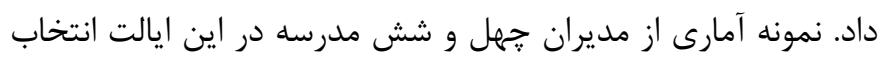

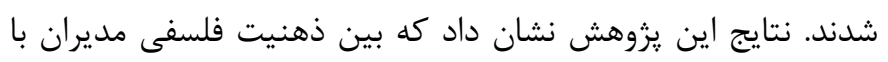

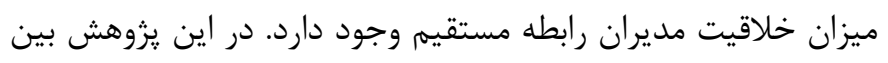

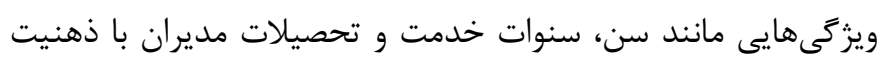

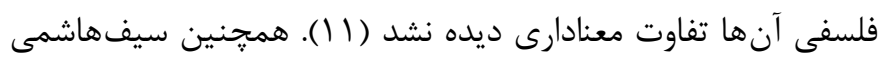

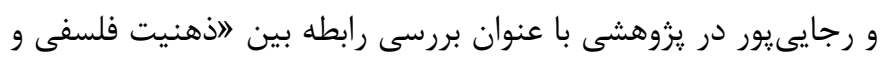

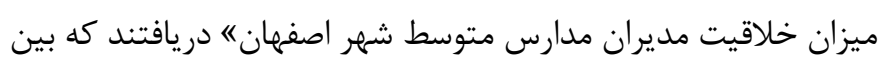

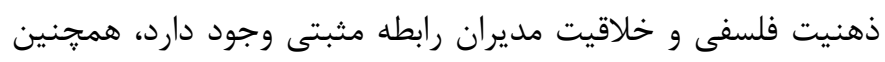

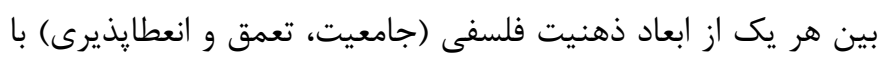

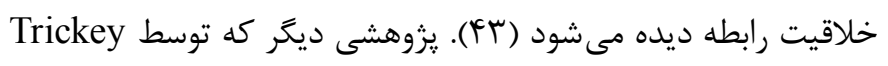

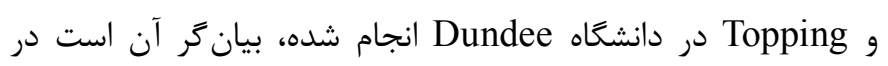
كلاسهايى كه خلاقيت و ذهنيت فلسفى تسهيل شده، احترام به خود أنداه و اعتماد به نفس شاكردان رشد يافته و شاكردان نسبت به به احساست دهات

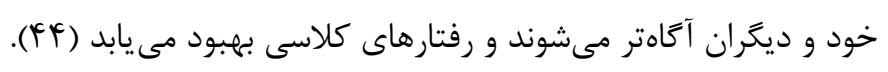

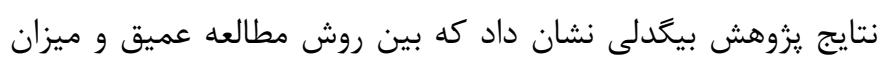

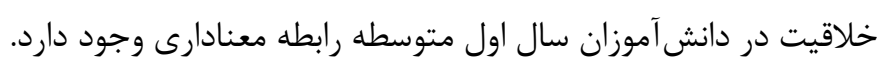

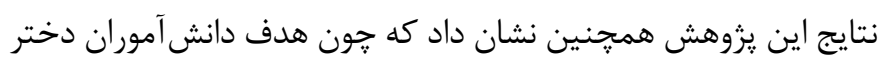

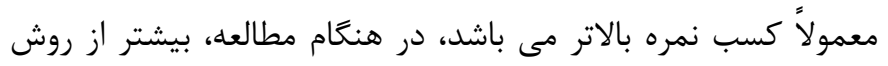

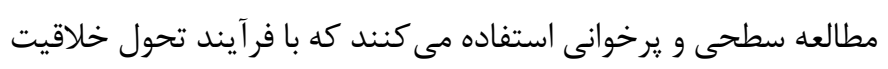

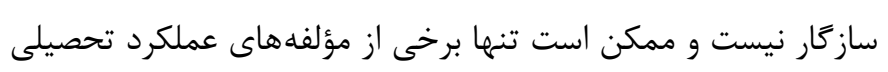

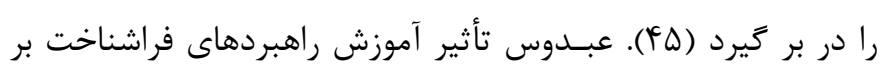

$$
\text { خلاقيت را مثبت ارزيابى كرد (ه) (؟). }
$$

با توجه به مطالب ذكر شده و باعنايت به اين كه نيروى محر كه و سرمايه

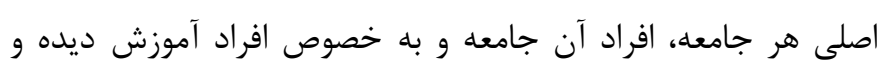

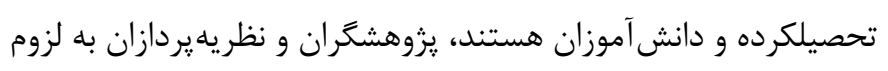

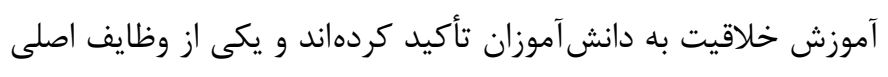

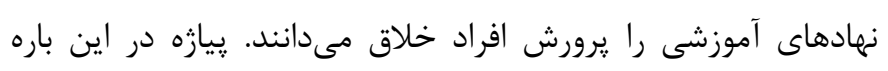

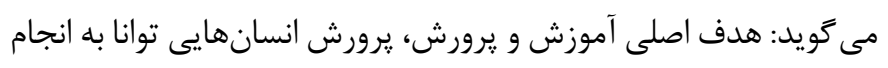

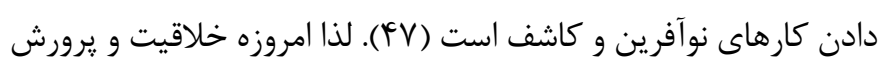

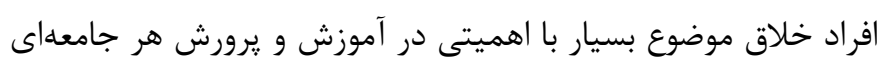

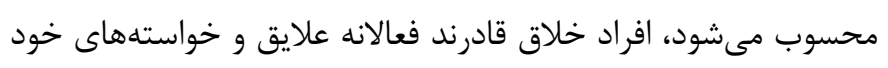

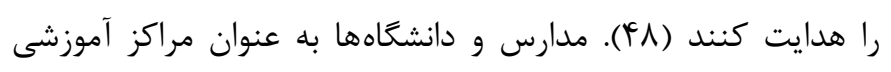

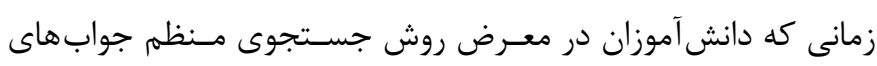

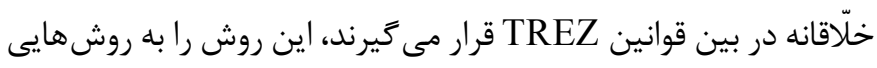

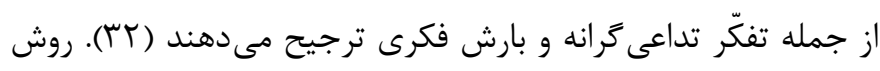

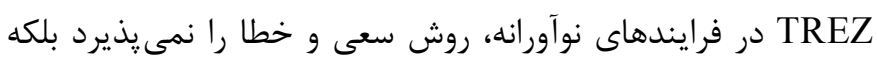

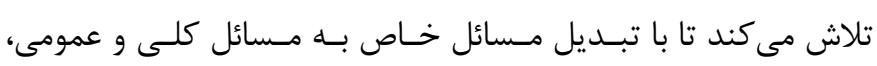

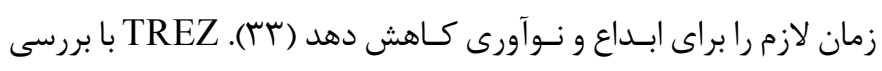

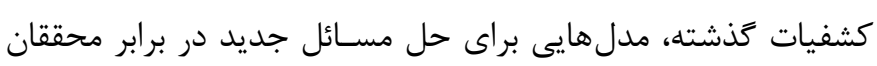

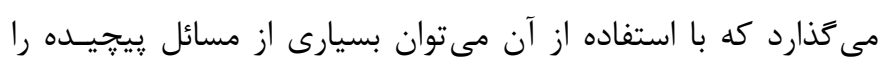

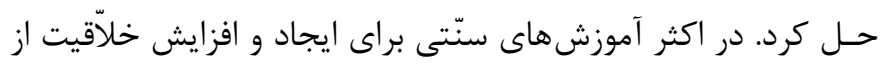

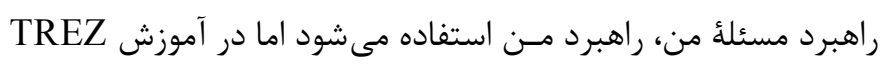

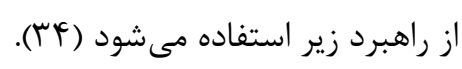

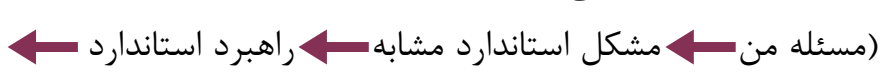

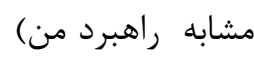

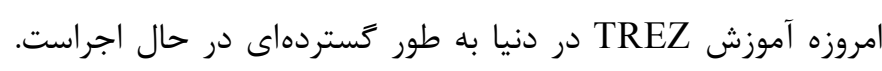

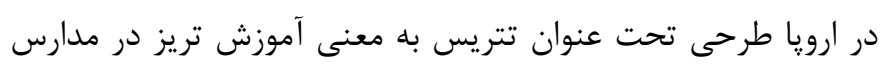

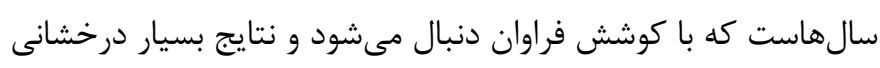

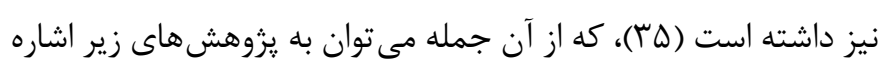

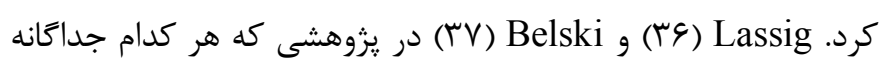
بر روى دانشجويان مهندسى انجام دادند نشان دادند كه اين دانشجويان

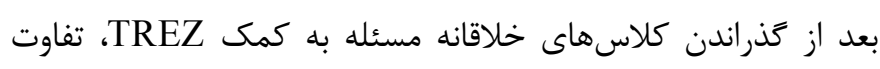

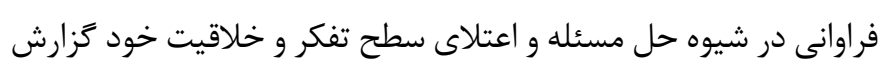

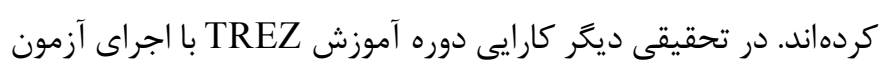

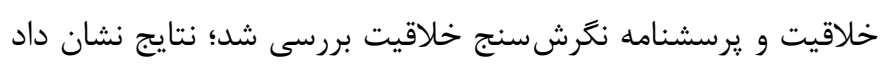

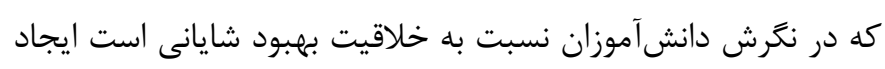

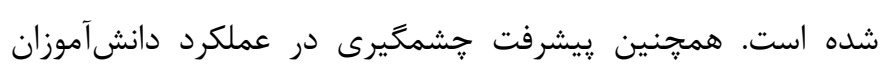

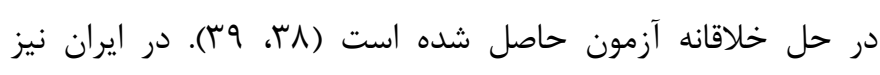

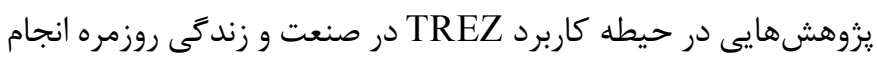

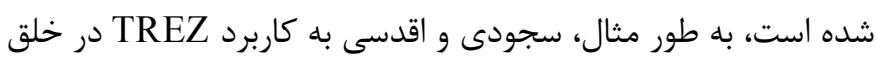

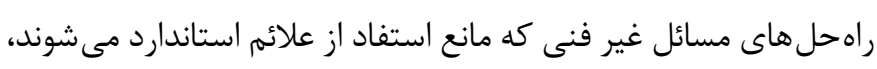

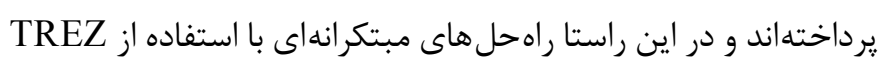

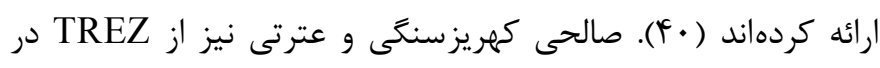
حل مشكلات فنى فرآيندها در صنعت نساجى استفاده كردهاند (Y) (Y).

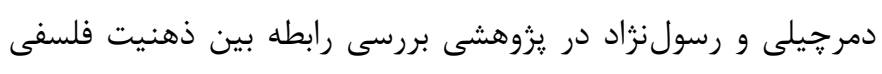

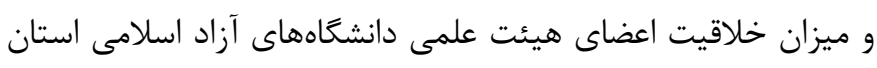

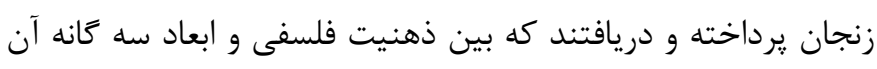

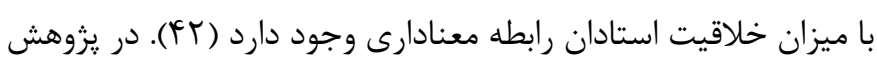

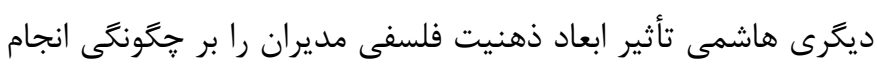


طيف ليكرت جهار كزينهاى از هركز=ا تا تقريباً هميشه=f باسخ داده

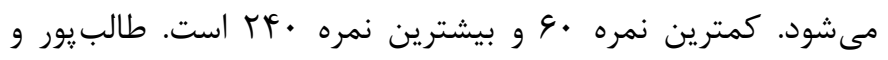

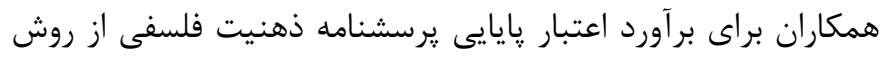

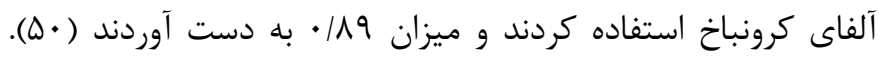

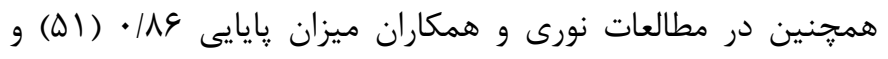

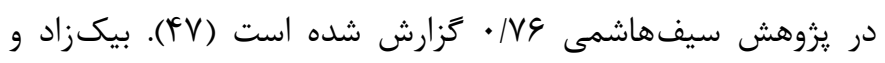

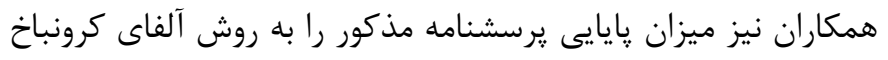

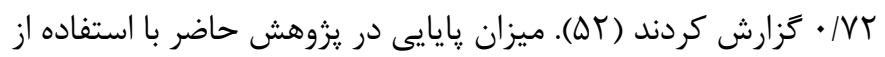
ضريب آلفاى كرونباخ برابر با لو • م محاسبه كرديد. يرسشنامه راهبردهاى فراشناختى (State Metacognitive Inventory):

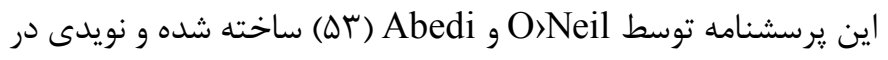

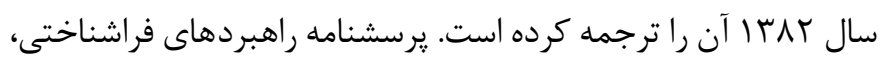

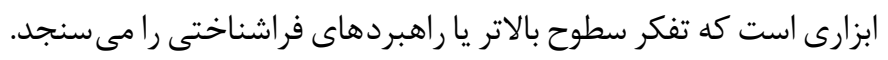

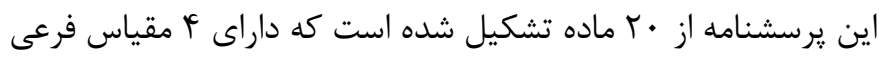

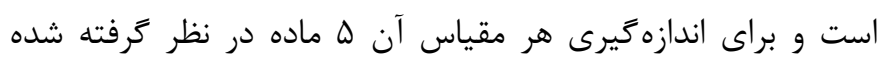

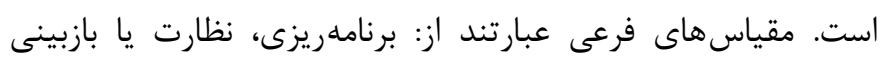

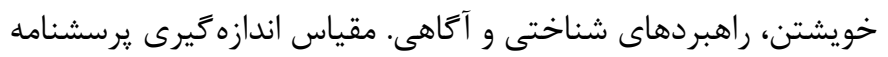

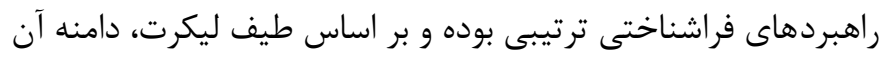

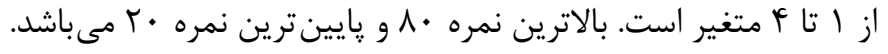

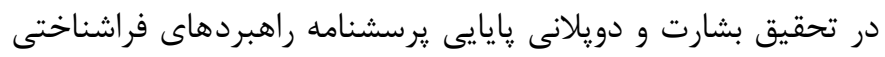

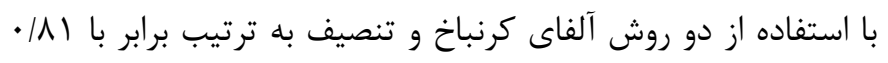

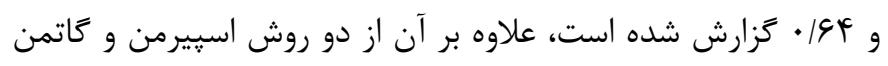

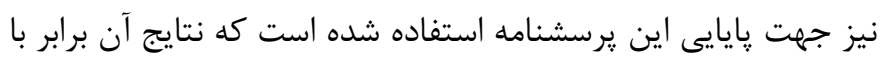

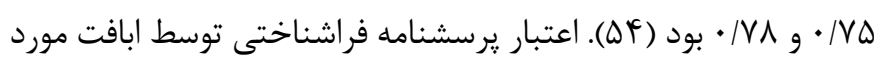

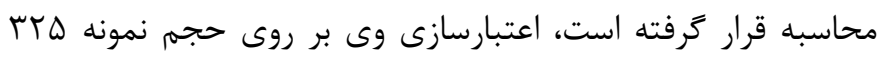

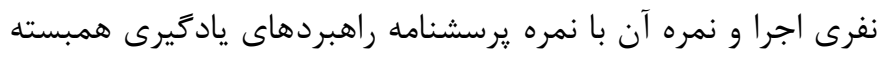
شد. طى اين مرحله مشخص گرديد همبستكى مثبت معنادارى بين

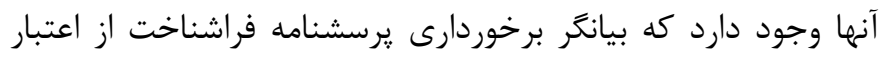

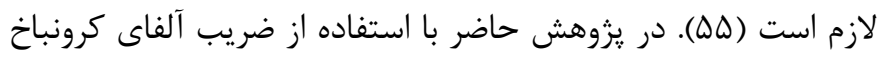
برابر با ||N| • محاسبه كرديد.

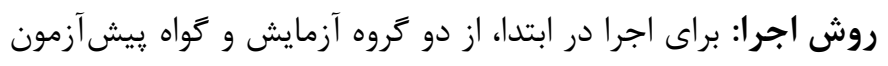

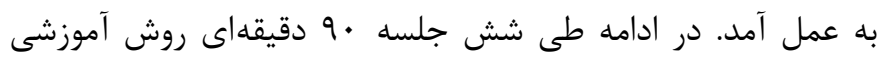

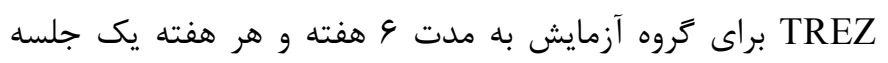

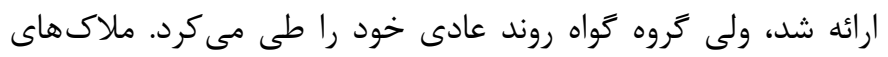

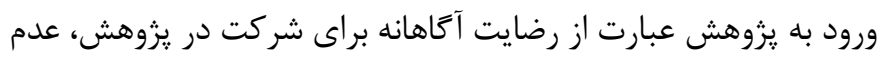
دريافت برنامه هاى مداخلهاى مشابه ملاك هاى خروج نيز داشتن سابقه بيمارى روانشناختى، داشتن غيبت بيش از دو جلسه و عدم تمايل به
رسمى، جمع كثيرى از نيروهاى جوان را در اختيار دارند كه بىترديد،

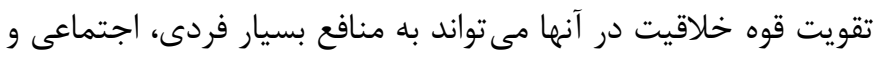
اقتصادى در هر جامعه منجر كردد (9q). همجنين با يِيشرفت روزافزون

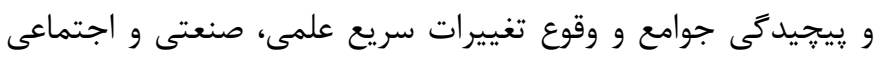

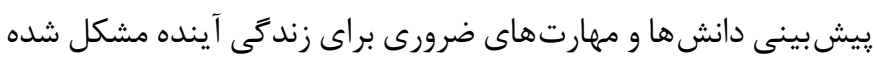

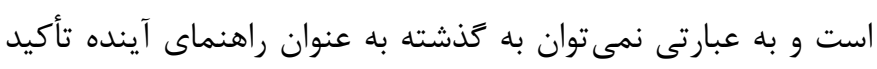

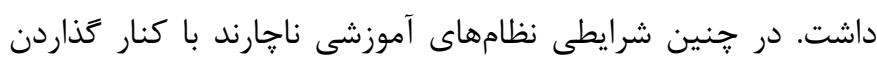

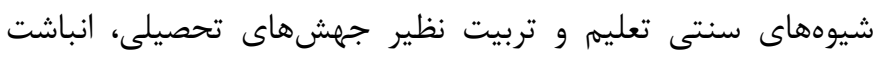

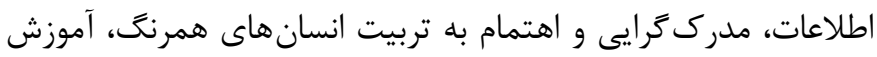

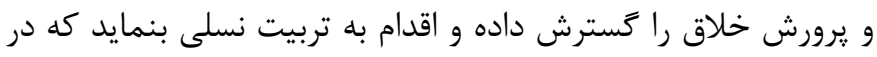

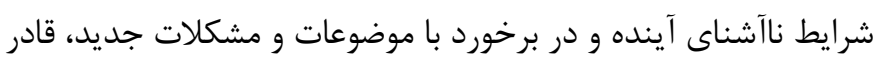

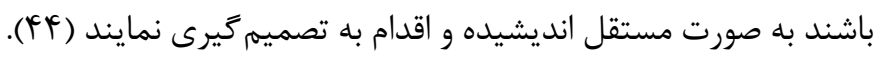

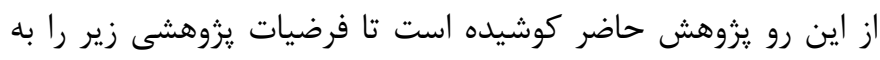

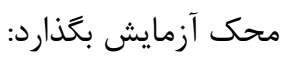
ו- آموزش TREZ بر ذهنيت فلسفى دانش آموزان دارد دختر بايه سوم دوره دوم متوسطه تأثير دارد. ז- آموزش TREZ بر مهارتهاى فراشناختى دانش آموزان دختر بايه سوم دوره دوم متوسطه تأثير دارد.

\section{روش كار}

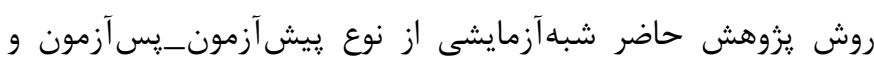

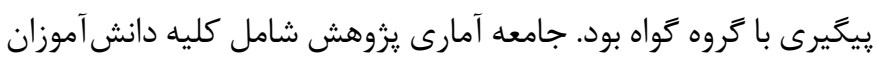

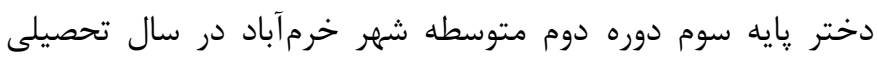
لو

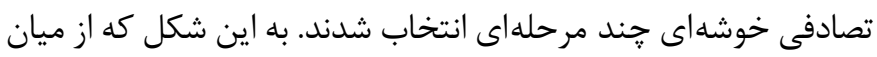

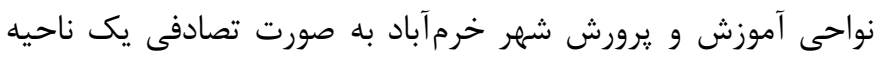

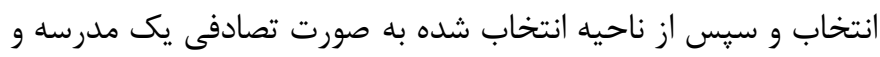

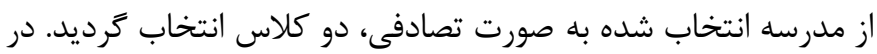

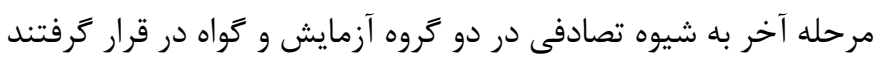

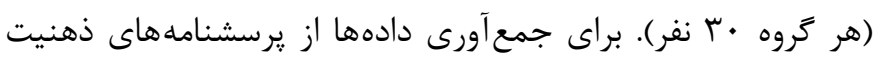

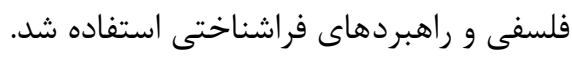

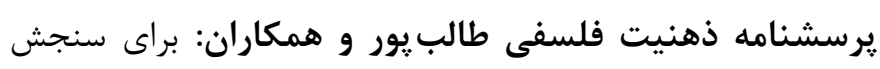

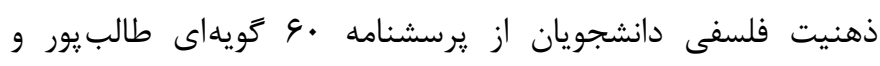

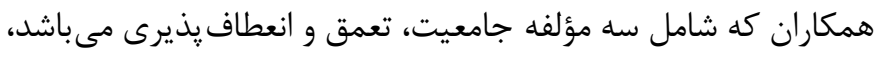

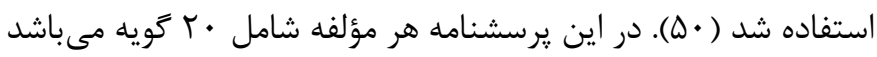

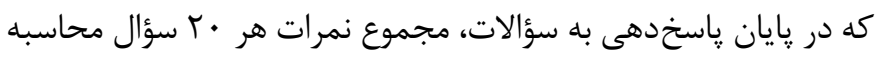

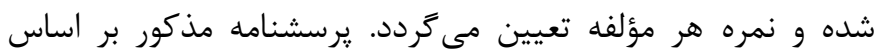


اخلاقى در گردآورى دادهها؛ صداقت در گزارش نتايج؛ عدم سوگيرى در تحليل دادهها؛ عدم ييشداورى در تحقيق؛ رعايت حريم خصوصى افراد نمونه گيرى و آزمايش و احترام به افراد جامعه يثوهش توسط يزوهشگران اعمال گرديد. جهت رعايت اصول اخلاقى، بعد از مرحله ييگيرى، گروه گواه به مدت ب جلسه به صورت فشرده تحت آموزش

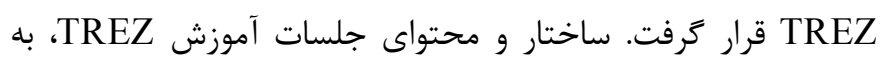
شرح جدول ا مى باشد.
همكارى در يزوهش بود. در جلسات آموزشى از روش ها و فنون تدريس اعم از سخنرانى، بحث گروهى و روش اكتشافى بنا به نياز استفاده شد. در ضمن برَزارى جلسات، تمرين هاى عملى يا نوشتارى به عنوان تكليف توسط دانشآموزان انجام شد. پس از اتمام آموزش، مجدداً هر دو گروه ارزيابى شدند و يك ماه بعد از اتمام جلسات آموزشى، دوره ييگيرى انجام شد. اخلاق در يزوهش از جمله امانتدارى در استفاده از منابع؛ دقت در استناددهى؛ قدردانى از ديخران؛ رعايت ارزشهاى

جدول ا. خلاصه جلسات آموزش TREZ

\section{خلاصه محتواى جلسات}

جلسات

آشنايى مقدماتى با TREZ و مختع آن، معرفى ه سطح نوآورى و خلاقيت تا دانشموزان از آنجه كه قرار است بياموزند به دركى كلى از اهميت و كاربرد آن برسند.

اولين قدم در راه اختراع يعنى خالش/مسئله توضيح داده شد كه در واقع همان قانون نقض TREZ است همجنين انواع تناقض يعنى تناقض فنى و فيزيكى و مثالهاى مختلف و متنوعى از هر ننع تناقض براى دانشآموزان توضيح داده شد و در ادامه تعريف مسئله (تناقضى) كه سعى در حل آن داريم. تعريف هدف نهايى يعنى حالت ايدهآلى كه مدنظر ما است توضيح داده شد و در يايان طحريزى فرصتهايى براى كاهش عامل مضر و يا افزايش

از بين •F قانون FREZ ق قانون كه براى دانش آموزان دوم دبيرستان قابل درك بود انتخاب شد و به دانشآموزان آموزش داده شد. در همين جلسه

نخستين قانون، يعنى قانون وارونهسازى آموزش داده شد و در انتهاى جلسه تمرينهايى مربوط به وارونهسازى بود توسط دانش آموزان حل شد تا

\section{يافته هـا}

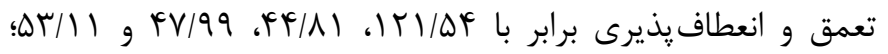
در مرحله يس آزمون برابر با ب مرحله ييگيرى به ترتيب برابر با ه

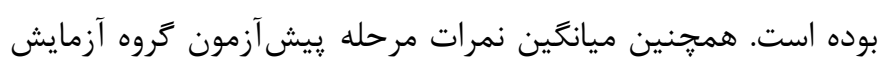
در راهبردهاى فراشناختى، برنامهريزى، نظارت، راهبردهاى شناختى و آكاهى، ل/AV TREZ راهبردهاى شناختى و آكاهى r r/F/

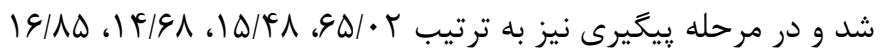

جدول r نتايج آمار توصيفى (ميانگين و انحراف معيار) دو گروه آزمايش

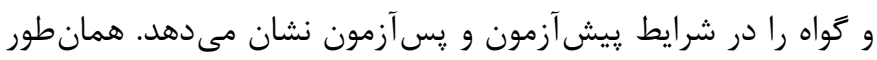
كه جدول r نشان مى دهد ميانگين نمرات مرحله ييش آزمون گروه

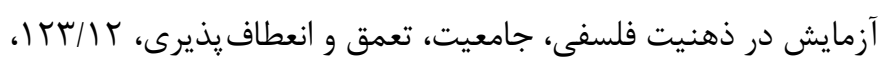
q مقادير در ذهنيت فلسفى، جامعيت، تعمق و انعطاف يذيرى 9 •//سا،

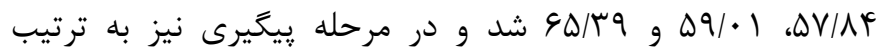
(4)/AV اين ميانگينها در مرحله يِيشآزمون براى ذهنيت فلسفى، جامعيت، 


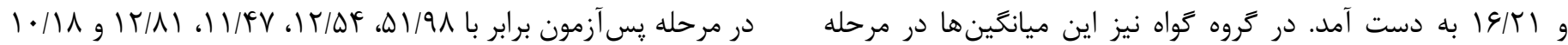

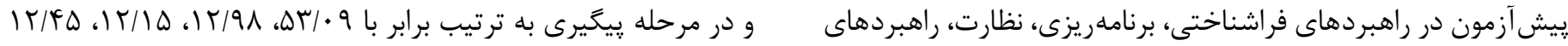

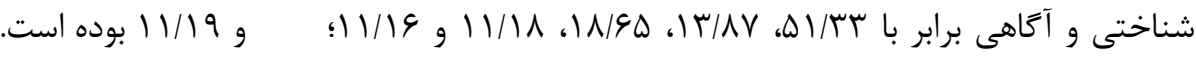
جدول r. شاخصهاى آمار توصيفى نمرات ذهنيت فلسفى و راهبردهاى فراشناختى آزمونىها بر اساس مرحله و عضويت كروهى

\begin{tabular}{|c|c|c|c|c|c|}
\hline \multicolumn{2}{|c|}{ كواه } & \multicolumn{2}{|c|}{ آزمايش } & \multirow{2}{*}{ مرحله } & \multirow{2}{*}{ متغيرها } \\
\hline انحراف معيار & ميانگين & انحراف معيار & ميانگين & & \\
\hline$N / \cdot r$ & $|r| / \Delta F$ & 1./1 & (T/K/T & يِيش آزمون & \multirow{3}{*}{ ذهنيت فلسفى } \\
\hline $9 / 99$ & (TM/gr & $11 / \pi$ & ( & يس آزمون & \\
\hline$\Delta / A^{+}$ & $\mid r \Delta / T \Delta$ & $11 / 1$. & IMI/AV & پيخيرى & \\
\hline $9 / V \wedge$ & 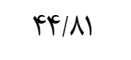 & $N / F$ & $f \Delta / r q$ & ييش آزمون & \multirow{3}{*}{ جامعيت } \\
\hline$r / l$. & $F T / 90$ & $\Delta / V \wedge$ & $\Delta V / A F$ & يس آزمون & \\
\hline$\Delta / 9 \Delta$ & $r q / \cdot r$ & g/VA & $\Delta q / T q$ & يِيخيرى & \\
\hline \&IAV & $F V / 99$ & $\Leftrightarrow / \wedge \Delta$ & FE/QT & يِيش آزمون & \multirow{3}{*}{ تعمق } \\
\hline$\Delta / A F$ & $r q / \Delta T$ & IV/FY & $\Delta 9 / \cdot 1$ & يس آزمون & \\
\hline F/TT & FN/AT & $\Delta / 1$. & $91 / 19$ & پيخيرى & \\
\hline $\mid F / A F$ & $\Delta r / I I$ & $1 \cdot \mid \omega F$ & $\Delta \Delta / A V$ & ييش آزمون & \multirow{3}{*}{ انعطاف يذيرى } \\
\hline$F / T)$ & $\Delta \cdot / \& \Delta$ & $1 f / 90$ & GF/MT & يس آزمون & \\
\hline $9 / 14$ & $\Delta T / T T$ & r/AV & GG/TT & يِيخيرى & \\
\hline $\mathrm{V} / \mathrm{IT}$ & س אום & $V / 11$ & $\Delta F / A V$ & ييش آزمون & \multirow{3}{*}{ راهبرد هاى فراشناختى } \\
\hline$\varepsilon / T \Delta$ & $01 / 91$ & $r / l i$ & $q q / \mu q$ & 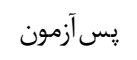 & \\
\hline$T / Y F$ & $\Delta r / \cdot 9$ & $F / r)$ & $9 \Delta / \cdot r$ & ي پيخيرى & \\
\hline$F / A V$ & IT/AV & $V / 9 \vee$ & $17 / 19$ & ي بيش آزمون & \multirow{3}{*}{ برنامهريزى } \\
\hline F/OT & $M / D F$ & $F / \Delta \Lambda$ & $\mid \omega / \Delta \Lambda$ & 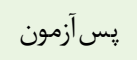 & \\
\hline $9 / 91$ & $1 r / 91$ & 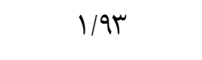 & $\mid Q / 4 \lambda$ & ي تيخيرى & \\
\hline $4 / 9 F$ & $11 / 90$ & $\mathrm{~V} / \Delta \mathrm{A}$ & $1 \cdot / r \Delta$ & ي بيش آزمون & \multirow{3}{*}{ 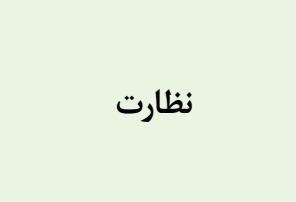 } \\
\hline$f / \wedge \Delta$ & $11 / \mathbb{F V}$ & $\Delta / 9)$ & $I F / A V$ & 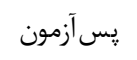 & \\
\hline $1 . / 14$ & $\mid r / 10$ & T/TY & $\mid f / 9 \Lambda$ & ي بيخيرى & \\
\hline $1 / \Delta F$ & $11 / 11$ & $1 \cdot / 4 \Delta$ & $11 / D F$ & ي بيش آزمون & \multirow{3}{*}{ راهبردهاى شناختى } \\
\hline$p / \wedge q$ & $|r / \Lambda|$ & $9 / \Delta \Lambda$ & $18 / 19$ & 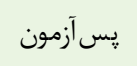 & \\
\hline$\varphi / 90$ & $\mid r / 4 \Delta$ & $r / T)$ & $19 / 1 \Delta$ & ي تيخيرى & \\
\hline $1 \cdot / 4 \Delta$ & $11 / 19$ & G/DF & $\mid r / 9 \pi$ & ي بيش آزمون & \multirow{3}{*}{ آتَاهى } \\
\hline$r / 90$ & $1 \cdot 111$ & r/VA & $\mid \Delta / 4 \Delta$ & يس آزمون & \\
\hline$r / 91$ & $11 / 19$ & $r / 9 \Delta$ & $|9 / T|$ & ِيخيرى & \\
\hline
\end{tabular}


(P>•/・日، $F=\mid r / \Delta V)$

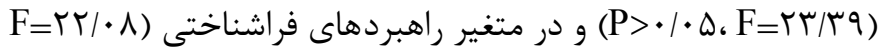

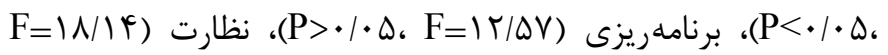

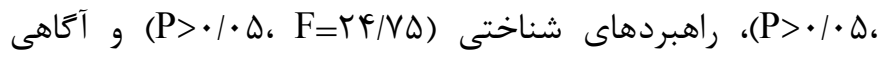
(P>•/•D، $F=19 / T F)$

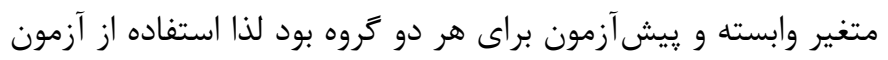
تحليل كوواريانس در بزوهش حاضر بلامانع بود. همانطور كه در جدول "ا، مشاهده مىشود يس إز خارج كردن بران اثر پِيشآزمون و ساير متغيرهاى كواه، به روش تحليل كوواريانس

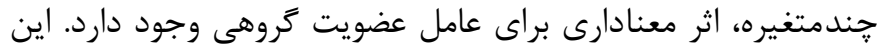
اثر جندمتغيره نشان مى دهد كه آموزش TREZ بر ذهنيت فلسفى و راهبردهاى فراشناختى دانش آموزان دختر پايه سوم دوره دوم متوسطه

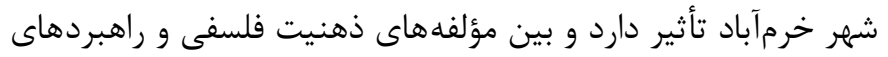

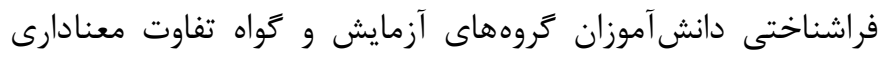

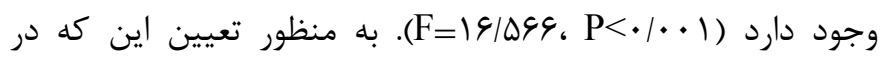

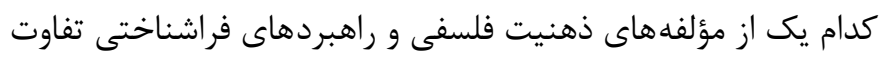

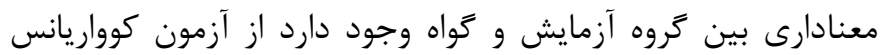
تكمتغيره استفاده شد كه نتايج آن در جدول أ و ه ارائه كرديده است.
براى بررسى تفاوت بين ذهنيت فلسفى و راهبردهاى فراشناختى و

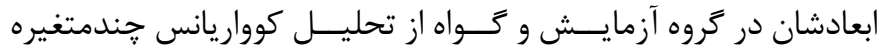
استفاده شد. براى استفاه از تحليل كوواريانس جندمتغيره ابتدا ييشفرضهاى آن بررسى شد. براى اطمينان از نرمال بودن توزيع

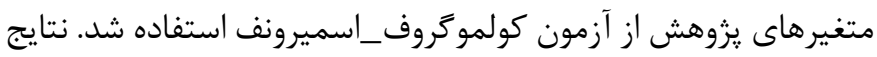

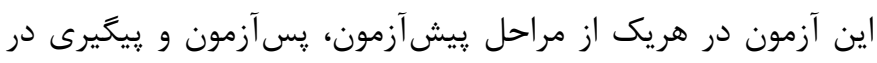

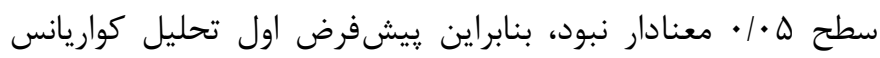

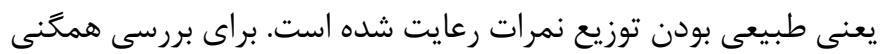

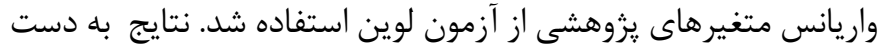

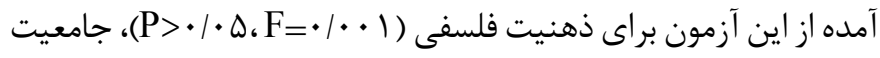

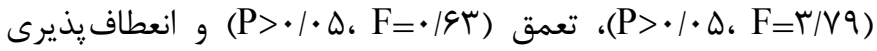
(P>•/•D، F=•|D\&)

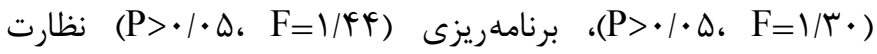

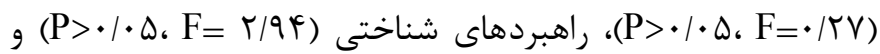

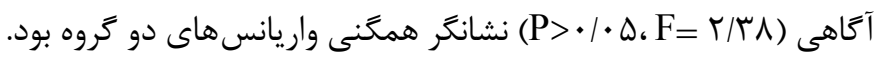

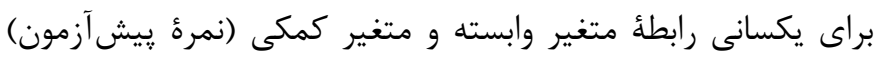

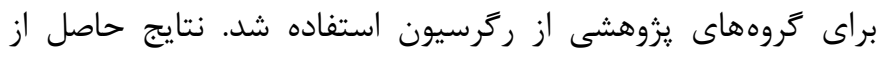

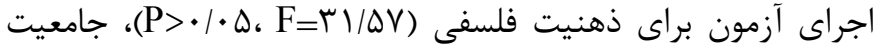

جدول r. نتايج تحليل كوواريانس حندمتغيره در مرحله پِ آزمون و يِيَيرى

\begin{tabular}{|c|c|c|c|c|c|c|}
\hline $\mathbf{P}$ & $\mathbf{F}$ & خطا Df & Df فرضيه Df & ارزش & آزمون & منبع \\
\hline$\cdot \mid \cdot \cdot 1$ & $19 / V T q$ & $\Delta \Delta$ & r & . ISAF & اثريبلايى & \multirow{4}{*}{ يس آزمون } \\
\hline$\cdot 1 \cdot .1$ & $19 / V T q$ & $\Delta \Delta$ & r & - rAA & لامبداى ويلكز & \\
\hline$\cdot \mid \cdot \cdot 1$ & 19/VTq & $\Delta \Delta$ & r & r/৭र९ & اثر هتلينت & \\
\hline$\cdot \mid \cdot \cdot 1$ & I $9 / V T q$ & $\Delta \Delta$ & r & r/Q19 & بزركترين ريشهروى & \\
\hline $.1 . \cdot 1$ & $19 / 099$ & $\Delta \Delta$ & r & $\cdot / N r$ & اثرييلايى & \multirow{4}{*}{ ييكيرى } \\
\hline$\cdot 1 . .1$ & $19 / \Delta 99$ & $\Delta \Delta$ & r & $\cdot / r V$ & لامبداى ويلكز & \\
\hline$\cdot 1 . .1$ & 191099 & $\Delta \Delta$ & r & $r / V \cdot$ & اثر هتلينت & \\
\hline$\cdot \mid \cdot \cdot 1$ & 191099 & $\Delta \Delta$ & r & $T / V \cdot$ & بزركترين ريشهروى & \\
\hline
\end{tabular}

تعمق و FV درصدى در مؤلفه انعطاف يذيرى، در كروه آزمايش در مرحله

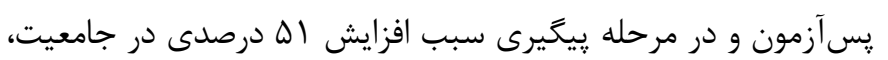

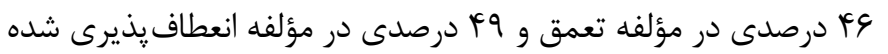
است. همجنين بالا بودن توان آمارى نشاندهنده دقت آمارى بالا و كفايت حجم نمونه در همه مؤلفههاى ذهنيت فلسفى است. اندازئ اثر نشان مى دهد مداخله مدّ نظر يّ از حَشت يك ماه ماندَار بوده است.
با توجه به جدول ₹ا، تفاوت بين نمرات مؤلفههاى ذهنيت فلسفى در

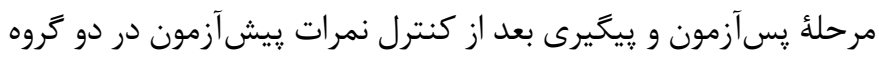

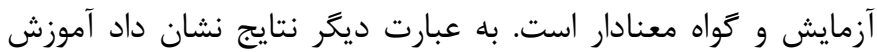
P< بر افزايش جامعيت (I TREZ

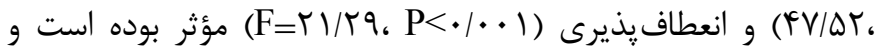
موجب افزايش qُ درصدى در مؤلفه جامعيت، ها درصدى در مؤلفه 
در مؤلفه راهبردهاى شناختى و FV درصدى در مؤلفه آكاهى، در گروه

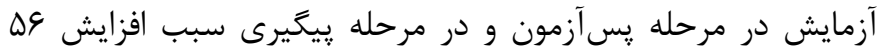
درصدى در مؤلفه برنامهريزى، س با درصدى در مؤلفه نظارت، \&\& درصدى در مؤلفه راهبردهاى شناختى و Fq درصدى در مؤلفه آكاهى شده است.

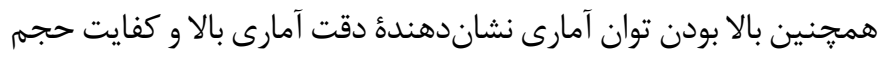
نمونه در همه مؤلفههاى راهبردهاى فراشناختى است. اندازء اثر نشان مى دهد مداخله مدّنظر پس از حذشت يكى ماه ماندًَار بوده است.
با توجه به جدول ه، تفاوت بين نمرات مؤلفههاى راهبردهاى فراشناختى

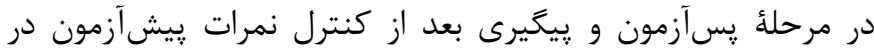
دو گروه آزمايش و گواه معنادار است؛ به عبارت ديگر نتايج نشان داد

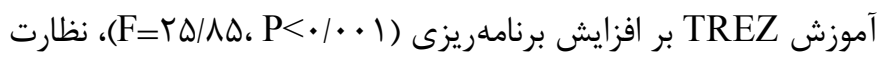

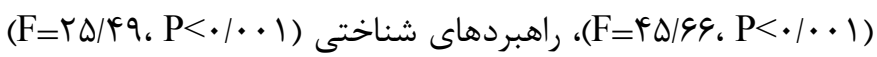

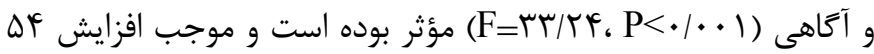
درصدى در مؤلفه برنامهريزى، • F درصدى در مؤلفه نظارت، FF درصدى

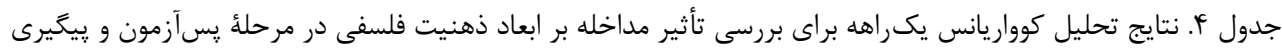

\begin{tabular}{|c|c|c|c|c|c|c|c|c|}
\hline توان آمارى & اندازه اثر & $\mathrm{P}$ & $\mathrm{F}$ & مجذذورات مينين & درآزادى & مجذمورع & تغيبرات & متغير وابسته \\
\hline$\cdot 1 \cdot V$ & $\cdot 1 \cdot 0$ & $\cdot / \cdot V$ & ه ט/ז & $\Delta q / \Gamma$. & 1 & $\Delta q / \Gamma$. & پيش آزمون & \multirow{3}{*}{ جامعيت } \\
\hline$\cdot / 9 V$ & $\cdot / 49$ & $\cdot \mid \cdot .1$ & $\Delta \Delta / ৭ \hookrightarrow$ & $9 \Lambda N / 9 \Lambda$ & 1 & $9 \Lambda \Lambda / 9 \Lambda$ & يس آزمون & \\
\hline .190 & $\cdot|Q|$ & $\cdot|\cdot \cdot|$ & $\Delta \varepsilon / T$ & $994 / \Delta 9$ & 1 & $99 \% / \Delta 8$ & קيخيرى & \\
\hline .1 .9 & $\cdot / 11$ & $\cdot / \cdot 1$ & $V / \Psi A$ & $V \varepsilon / M$ & 1 & $V \varepsilon / 11$ & پيش آزمون & \multirow{3}{*}{ تعمق } \\
\hline$\cdot / A V$ & $\cdot / 4 \Delta$ & $\cdot \mid \cdot \cdot 1$ & FV/DT & FAY/AF & 1 & FAT/AF & يس آزمون & \\
\hline 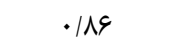 & $\cdot / 49$ & $\cdot|\cdot \cdot|$ & FN/TA & $F q \Lambda / 4 r$ & 1 & FqN/Fr & پيخيرى & \\
\hline$\cdot 1 \cdot 1$ & $\cdot \mid \cdot \cdot 1$ & $\cdot / 19$ & $\Delta / \cdot r$ & $11 / \cdot v$ & 1 & $11 / \cdot v$ & يِيش آزمون & \multirow{3}{*}{ نعطاف يذيرى } \\
\hline$\cdot 191$ & $\cdot / 4 V$ & $\cdot / \cdot \cdot 1$ & $r I / r q$ & $V \lambda \cdot / r$. & 1 & $V \lambda \cdot / r$. & يس آزمون & \\
\hline .119 &.$/ 49$ & $\cdot / \cdot .1$ & Tr/Tq & $\checkmark \wedge \Delta / 1 Q$ & 1 & $\vee \wedge \Delta / 1 \Delta$ & ييخيرى & \\
\hline
\end{tabular}

جدول ه. نتايج تحليل كواريانس يك راهه براى بررسى تأثير مداخله بر ابعاد راهبردهاى فراشناختى در مرحلهُ پِآزمون و پِيخيرى

\begin{tabular}{|c|c|c|c|c|c|c|c|c|}
\hline توان آمارى & اندازه اثر & $\mathrm{P}$ & $\mathrm{F}$ & مجذانگين & آزادى درجه & مجذوروات & تغييرات & متغير وابسته \\
\hline .1 .9 & $\cdot 1 \cdot 1$ & $\cdot / \mu \Lambda$ & $\cdot 1 \Delta \Delta$ & 19/AV & 1 & 19/AV & ِيش آزمون & \multirow{3}{*}{ برنامه ريزى } \\
\hline . 194 & $\cdot \mid \Delta F$ & $\cdot \mid \cdot \cdot 1$ & $r \Delta / \wedge \Delta$ & $\mid F \Delta \Delta / F \Delta$ & 1 & $\mid f \Delta \Delta / F \Delta$ & يس آزمون & \\
\hline$\cdot / 91$ & $\cdot \mid \Delta \Phi$ & $\cdot / \cdot \cdot 1$ & TY/MY & $\mid \& 99 / 90$ & 1 & $\mid \& \& 9 / 90$ & ِيخيرى & \\
\hline .1 .4 & $\cdot / \pi$ & .1 .9 & T/QF & GI/QT & 1 & SI/DT & ِيش آزمون & \multirow{3}{*}{ نظارت } \\
\hline$\cdot \mid \Lambda 9$ & $\cdot / 4$ & $\cdot|\cdot \cdot|$ & $F \Delta / \varphi q$ & VFF/YF & 1 & VFF/TF & يس آزمون & \\
\hline$\cdot \mid A V$ & . I & $\cdot / \cdot \cdot 1$ & Tr/Tr & $V \Delta \& \mid \& \Delta$ & 1 & $V \Delta \& \mid \xi \Delta$ & ييخيرى & \\
\hline.$/ 11$ &.$/ 1$ & .1 .9 & $\Delta / \Delta F$ & سז/1 & 1 & Mואו & يِيش آزمون & \multirow{3}{*}{ شناختى راهبرد } \\
\hline$\cdot 119$ & $\cdot /$ Aq $^{-}$ & $\cdot \mid \cdot \cdot 1$ & $r q / T \Delta$ & $r \varphi \Delta / \wedge F$ & 1 & rGQ/AF & يس آزمون & \\
\hline$\cdot \mid \mathrm{M}$ &.$/ 48$ & $\cdot|\cdot \cdot|$ & FN/TF & rGq/א & 1 & rGq/4 & پيخيرى & \\
\hline .1 .9 & $\cdot / \cdot \cdot r$ & $\cdot / V V$ & $91 \cdot 9$ & $19 / \cdot 9$ & 1 & $19 / \cdot 9$ & پِيش آزمون & \multirow{3}{*}{ آكاهى } \\
\hline . 194 & $\cdot / F V$ & $\cdot \mid \cdot \cdot 1$ & MT/TY & $\Lambda V Y / r$. & 1 & AVH/r. & يس آزمون & \\
\hline$\cdot / 91$ &.$/ 49$ & $\cdot \mid \cdot \cdot 1$ & rI/AV & $\lambda V \cdot / 1 Q$ & 1 & $\Lambda V \cdot / 1 Q$ & بيخيرى & \\
\hline
\end{tabular}


آموزش TREZ بر ذهنيت فلسفى دانشآموزان دختر يايه سوم دوره دوم متوسطه شهر خرمآباد تأثير مثبت و معنادارى دارد. يافته الهاى داى دان يزوهش حاضر با نتايج يزوهشهاى Smith (1)، هاشمى (1) (1)،

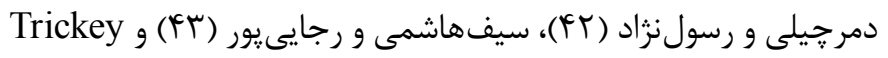

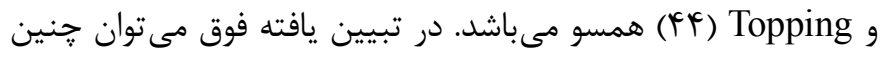
استنباط كرد كه تفكر منطقى، حاصل داشتن ذهن فلسفى است. تفكر منطقى و فلسفى لازمه حل مشكلات تحصيلى است (با ()). دانش آموز

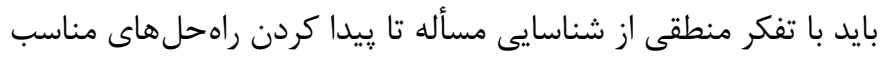
براى مشكلات يِيش برود و اين كار امكانيذير نيست، جز اين كه از خصوصيات تفكر منطقى برخوردار باشد. بنابراين در راستاى افزايش تفكر منطقى يكى از اين ابزارها، داشتن ذهن فلسفى است كه افراد را در

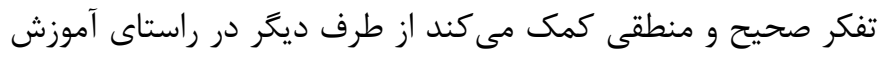

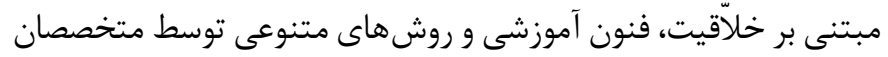

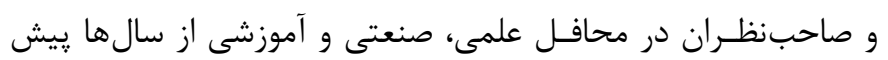

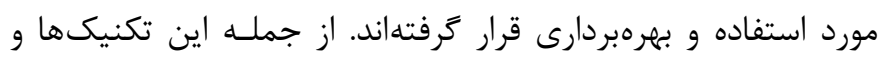

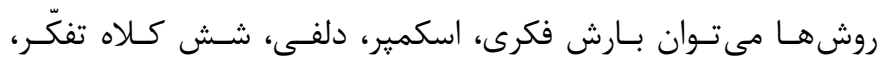

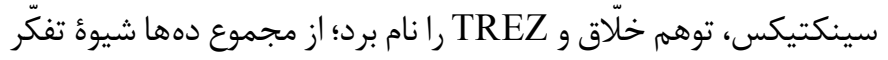

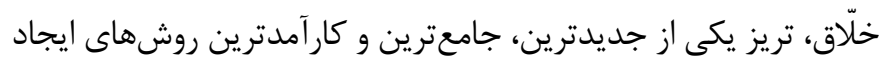
و افزايش خلاقيت در افراد مختلف از جمله دانش آموزان و دانشجويان

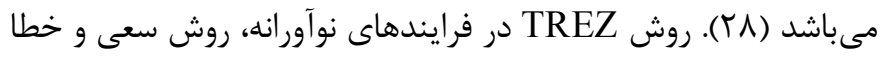

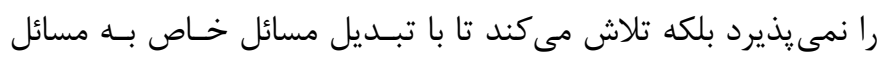

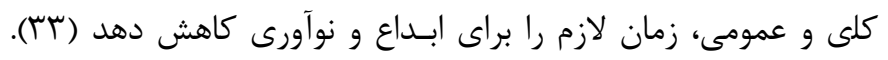

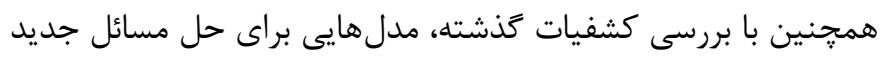

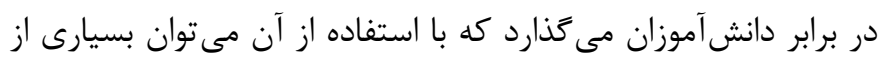

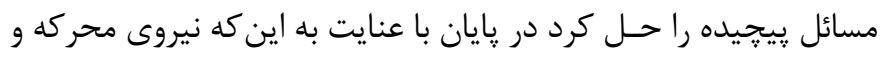

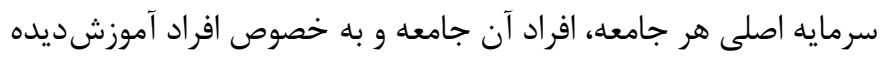

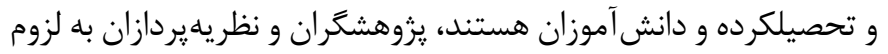

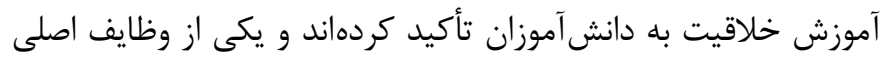

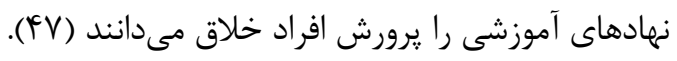

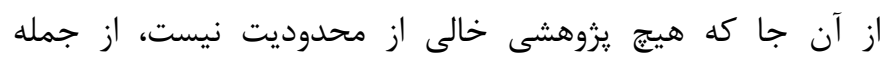

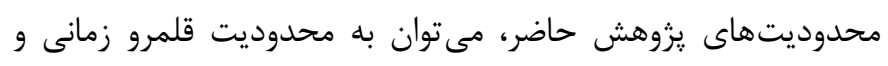

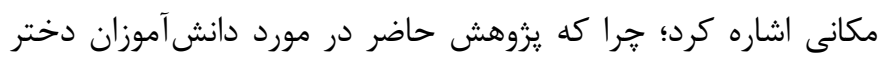

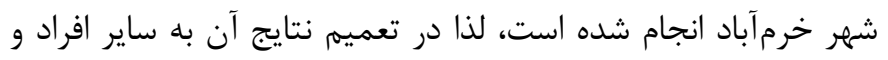

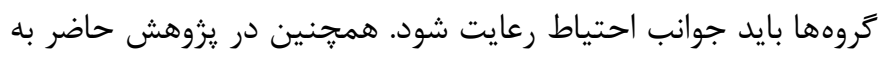
منظور تردآورى دادهها از برسشنامه استفاده گرديد، در نتيجه ممكن است برخى از افراد از ارائه ياسخ واقعى خوددارى كرده و ياسخ غير

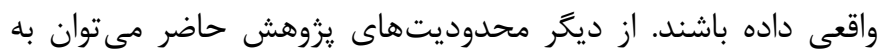

هدف كلى يزوهش حاضر، تأثير آموزش TREZ بر راهبردهاى فراشناختى

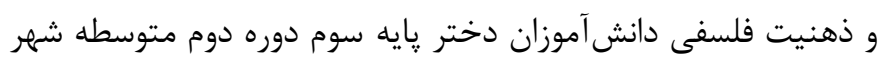

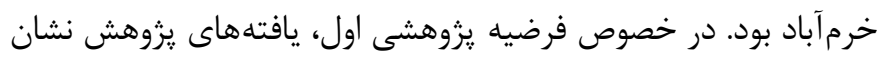

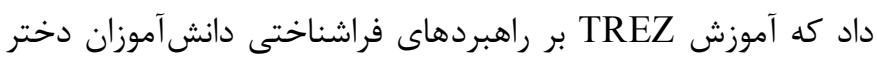

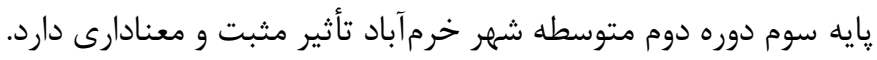

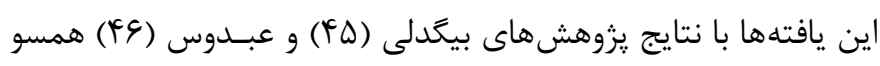

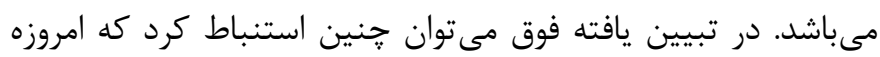
مشكل بيشتر دانشآموزان اين است كه ياد نكرفتهاند كه جِكونه ياد

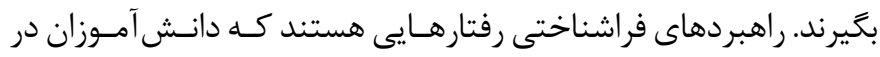

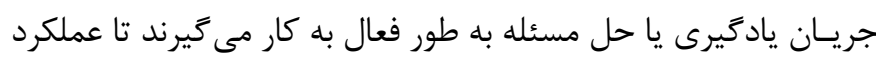

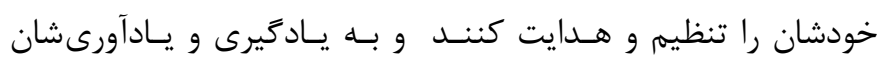

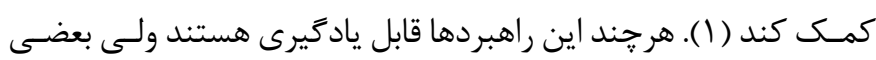

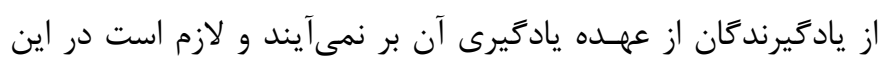

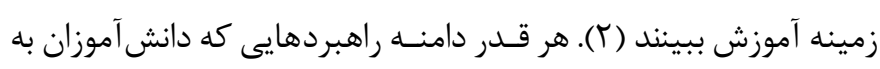

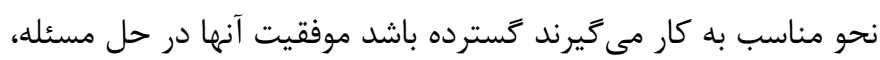
خلاقيت، خواندن، درى مطلب و بـه خاطرسيارى اطلاعات بيشتر است

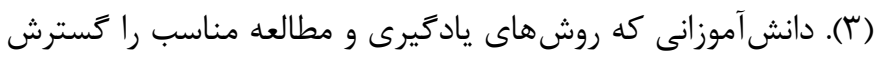

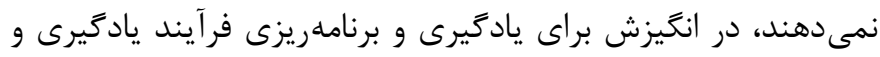

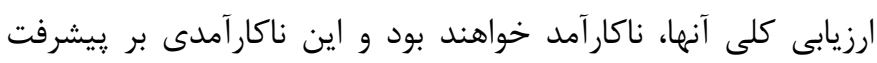

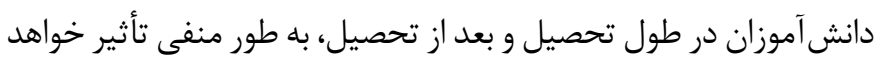

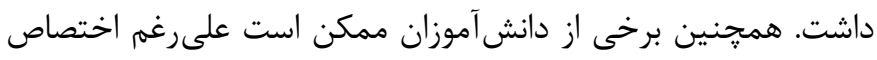

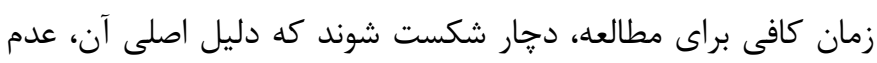

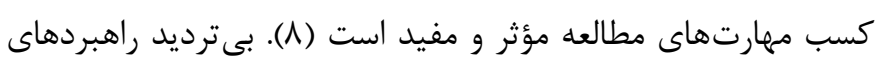

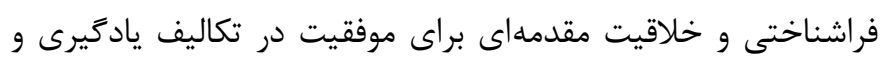

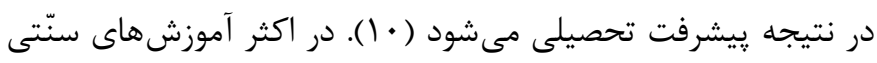
براى ايجاد و افزايش خلاّقيت از راهبرد مسئلهُ من و راهبرد من استفاده

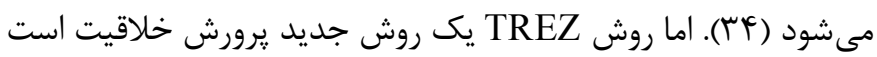

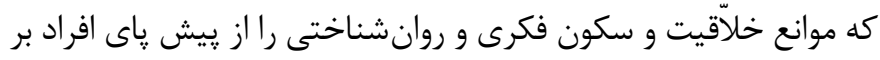

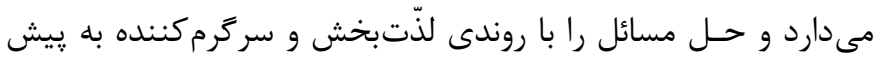

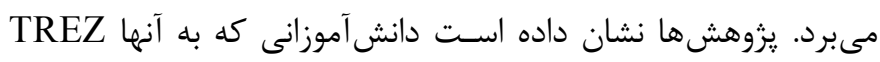

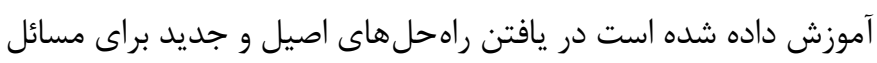

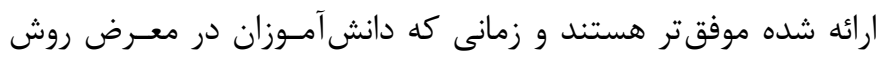

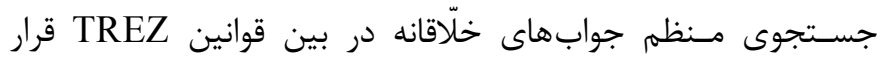

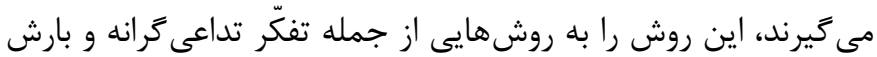
فكرى ترجيح مى دهند (זس). در خصوص فرضيهى يزوهشى دوم نيز يافتهاى يزوهش نشان داد كه 


\section{نتيجه كيرى}

مى توان نتيجه كرفت كه روش مزبور بر ذهنيت فلسفى و راهبردهاى

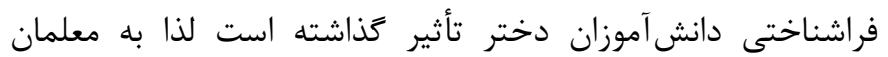

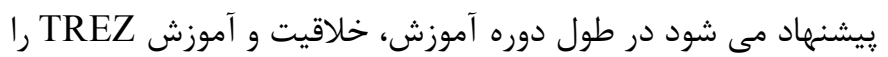
به دانش آموزان ارائه دهند.

\section{تشكر و قدروانى}

در يايان از مساعدت هاى تمامى عوامل به ويزه مديريت محترم آموزش

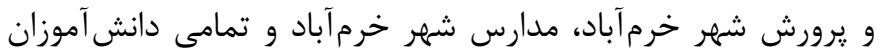
عزيزى كه بى دريخ در روند يزوهش حاضر ما را يارى نمودند، صميمانه

$$
\text { سياسگزارى مى تردد. }
$$

\section{References}

1. Abedi J. Creativity and a new way of measuring it. Psychological Research. 1993;3(1-2):34-46. (Persian)

2. Saif AA, Mesrabady J. The effectiveness of learning strategies on reading speed, retention and understanding of different texts. Journal of Education. 2003;19(74):54-37. (Persian)

3. Farrokhi N. Investigating the effectiveness of training cognitive and metacognitive strategies on reading comprehension of Guidance school boys pupils. Quarterly of Educational Psychology. 20106(8):130-154. (Persian)

4. Eggen P, Kauchak D. Educational psychology windows on classrooms. 5th ed. New Jersey:Merrill Prentice Hall;2001.

5. Flavell JH. Development of children's knowledge about the mental world. International Journal of Behavioral Development. 2000;24(1):15-23.

6. Aghazadeh M. A guide to modern teaching methods. Tehran:Aeezh Publication;2005. (Persian)

7. Vitae T. Metacognition is the awareness and control of one's own cognition [Doctoral Dissertation]. Baltimore:University of Maryland;2010

8. Dilekmen M. Sukru A. Alver B. An evaluation on study skills of high school students. Word Applied Sciences Journal. 2009;6(7):966-970.
نبود امكان در افزايش تعداد جلسههاى آموزشى اشاره كرد. يِيشنهاد مىشود در يروهش هاى آتى تعداد جلسه هاى آموزشى افزايش يابد و شاخههاى دانش ديخر TREZ مانند Usit و Ariz بر ميزان ذهنيت فلسفى و راهبردهاى فراشناختى دانش آموزان نيز بررسى شود. همجنين ״يشنهاد مىشود اين يزوهش در بين ساير افراد و مقاطع تحصيلى مختلف ، بالاخص دانشجويان نيز اجرا شود. بديهى است كه ييادهسازى و به كار گيرى صحيح و اثربخش هر دانشى مستلزم درك عميق و شناخت صحيح از فلسفه و روابط ميان اجزاى آن دارد، از آن جا كه TREZ نيز از اين قاعده مسثتنى نمىباشد لذا ييشنهاد مى شود براى ييادهسازى و به كارگيرى صحيح روش TREZ از نكاه سطحى و كوتاه بينانه به آن اجتناب شود در غير اين صورت از TREZ و هر دانشى جز شعار و بيان يارهاى مفاهيم و اصطلاحات نمى توان انتظارى فراتر داشت.

9. Githua BN, Mwangi JG. Students' mathematics self-concept and motivation to learn mathematics: relationship and gender differences among Kenya's secondary-school students in Nairobi and Rift Valley provinces. International Journal of Educational Development. 2003;23(5):487-499.

10. Eilers LH, Pinkleyey Ch. Metacognitive strategies help students to comprehend all text Reading improvement. Reading Improvement. 2006;43(1):13-29.

11. Smith P. What is philosophy education?. USA:MacMillan;2001.

12. Shariatmadari Ali. Principles of education and training. Tehran:Tehran University Press;2013. (Persian)

13. Mirkamali SM. Behavior and relationships in organization and management. Tehran:Eustaver Publishing;2007. (Persian)

14. Michael JH. Problem solving in business and management. New York:Springer;1991.

15. Hashemi SA. Investigating the impact of the dimensions of philosophical concepts of managers on how to perform management tasks [MSc Thesis]. Tehran:Islamic Azad University, Central Tehran Branch;2006. (Persian)

16. Samadaghaee J. Creative essence of entrepreneurship. Tehran:Tehran University Press;2014. 
17. Lipman M, Sharp AM. Teaching children philosophical thinking: An introduction to the teacher's manual for" Harry Stottlemeier's Discovery". Montclair, NJ:Institute for the Advancement of Philosophy for Children;1975.

18. Webster Dictionary of the English language. New York:Merriam-webster;2003.

19. Bentley T. Distributed intelligence: Learning and creativity. Nottingham:National College for Leadership;2002. pp. 1-6.

20. Runco MA, Jaeger GJ. The standard definition of creativity. Creativity Research Journal. 2012;24(1):92-96.

21. Vidal RV. Creativity for operational researchers. Operational Research. 2005;25(1):1-24.

22. Ghasemzadeh H. Creativity, promising a brilliant future for all human beings. Rahyaft. 2001;11(26):66-74. (Persian)

23. Hosseini A. The nature of creativity and its breeding methods. Mashhad:Behnshar;2015. (Persian)

24. Craft A, Jeffrey B, Leibling M. Creativity in education. London:Continuum;2001.

25. Ganji K, Niusha B, Hedayati F. The effect of creativity training to mothers on creativity of their preschool children. Quarterly Journal of Innovation and Creativity in Human Sciences. 2012;2(2):71-93. (Persian)

26. Dorostian E, Mirzakhani P. Investigation the effect of mother's group training on increasing children's creativity: With emphasis on transactional analysis theory. Quarterly Journal of Innovation and Creativity in Human Sciences. 2012;2(1):85105. (Persian)

27. Afsharkhan Z, Asareh A. The effect of creativity training to teachers on the creativity of the first primary grade students in Khorasan in the academic year 88-89. Quarterly Journal of Innovation and Creativity in Human Sciences. 2011;1(2):2955. (Persian)

28. Nakagawa T. Education and training of creative problem solving thinking with TRIZ/USIT. Procedia Engineering. 2011;9:582-595.

29. Scheiner CW, Baccarella CV, Bessant J, Voigt KI. Thinking patterns and gut feeling in technology identification and evaluation. Technological Forecasting and Social Change. 2015;101:112-123.

30. Van Pelt A, Hey J. Using TRIZ and human-centered design for consumer product development. Procedia Engineering. 2011;9:688-693.

31. Loh HT, He C, Shen L. Automatic classification of patent documents for TRIZ users. World Patent Information. 2006;28(1):6-13.

32. Kannengiesser U, Williams Ch, Gero J. What do the concept generation techniques of triz, morphological analysis and brainstorming have in common. TRIZ Journal. 2012;182(1):4589.

33. Stratton R, Mann D. Systematic innovation and the underlying principles behind TRIZ and TOC. Journal of Materials Processing Technology. 2003;139(1-3):120-126.

34. Barak M, Goffer N. Fostering systematic innovative thinking and problem solving: Lessons education can learn from industry. International Journal of Technology and Design Education. 2002;12(3):227-247.

35. Marsh D, Waters F, Mann D. Using TRIZ to resolve educational delivery conflicts inherent to expelled students in Pennsylvania. TRIZ Journal. 2002;7:1-11.

36. Lassig CJ. Approaches to creativity: How adolescents engage in the creative process. Thinking Skills and Creativity. 2013;10:3-12.

37. Belski I. TRIZ course enhances thinking and problem solving skills of engineering students. Procedia Engineering. 2011;9:450-460.

38. Simonton DK. Taking the US Patent Office criteria seriously: A quantitative three-criterion creativity definition and its implications. Creativity Research Journal. 2012;24(2-3):97106.

39. Khomenko N, Sokol A. New models and methodology for teaching OTSMTRIZ. TRIZCON-2000. In International conference of the Altshuller institute. Nashua, New Hamphire, USA;2000.

40. Sojoodi A, Aqdasi M. The use of TRIZ to create solutions 
to non-technical issues by preventing the use of standard marks [MA Thesis]. Tehran:Tarbiat Modares University;2004. (Persian)

41. Salehik Farzizani A, Etrati SM. Trases in solving technical problems of processes in the textile industry. [MA Thesis]. Tehran:Tarbiat Modares University;2002.

42. Damerchili F, Rasoulnejad A. The relationship between philosophic-mindedness and creativity among faculty members of IAU Zanjan branch. Journal of Modern Thoughts in Educational. 2009;4(1):45-62. (Persian)

43. Saifhashmi F, Rajayapour S. Investigating the relationship between philosophical subjectivity and creativity of high school principals in Shahr Esfahan. Quarterly Journal of Education. 2004;20(1):31-46. (Persian)

44. Trickey S, Topping KJ. Collaborative philosophical enquiry for school children: Socio-emotional effects at 11 to 12 years. School Psychology International. 2006;27(5):599-614.

45. Bidgoli M. Investigating the relationship between study methods and motivational structure with creativity in high school students [MSc Thesis]. Tehran:Islamic Azad University, Abhar Branch;2013. (Persian)

46. Abdous M. The effect of teaching meta-cognitive strategies on creativity development of 3rd-year-old girl students in high school in Tehran [MSc Thesis]. Tehran:Alzahra University;2001. (Persian)

47. Saif Hashemi F. The relationship between creativity and personality characteristics of high school students in Tehran. Magazine Educational Innovations. 2014;3(7):12-24. (Persian) 48. Tan AG. Creativity: A handbook for Teachers. Singa-
pore:World Scientific Publishing;2007.

49. Kazemi Y, Jafari N. Teachers $\backslash$ 'characteristics and activities as impediments to students $\backslash$ 'creativity. Quarterly Journal of New Thoughts on Educational. 2008;4(1):177-192. (Persian) 50. Talebpour M, Hosseini A. Jabari H, Jabari M. Study and comparison of physical mindedness of managers, different sport team coaches, team supervisors in Iran universities. Research on Sports Science. 2012;7(2):109-131. (Persian)

51. Nouri S, Fayyaz I. Seif A. Effect of philosophical mentality on solving math problems by male and female third-grade students in Hamedan junior high schools. Tafakkor Va Kudak. 2013;4(7):121-139. (Persian)

52. Jafar B, Beigzadeh J, Dadashi MS. The relationship between social intelligence of managers, their philosophical mentality and organizational health of schools in three educational stages of Bonab city. Journal of Cultural Management. 2010;5(7):69-84. (Persian)

53. O’Neil Jr HF, Abedi J. Reliability and validity of a state metacognitive inventory: Potential for alternative assessment. The Journal of Educational Research. 1996;89(4):234-245. 54. Abbaspour Doplani T, Besharat MA. The relationship between metacognitive strategies and creativity with resilience among university students. New Findings on Psychology. 2010;5(14):109-122. (Persian)

55. Abaft $\mathrm{H}$. The relationship between metacognitive strategies, self-efficacy and parental parenting practices with academic self-maladaptation in high school students in Ahwaz [MA Thesis]. Ahvaz:Islamic Azad University, Ahvaz Branch;2009. (Persian) 